\title{
Arenigian tholeiitic basalts in the Famatina Ordovician basin, northwestern Argentina: emplacement conditions and their tectonic significance
}

\author{
*Clara Eugenia Cisterna ${ }^{1}$, Magdalena Koukharsky", Beatriz Coira ${ }^{2}$, \\ Christina Günter ${ }^{3}$, Horstpeter H. Ulbrich ${ }^{4}$
}

\author{
I Facultad de Ciencias Naturales, Universidad Nacional de Tucumán, Consejo Nacional de Investigaciones Científicas y Técnicas, \\ Miguel Lillo 205, 4000 Tucumán, Argentina. \\ claracisterna@csnat.unt.edu.ar \\ 2 Instituto de Ecorregiones Andinas, Consejo Nacional de Investigaciones Cientificas y Técnicas, Universidad Nacional de Jujuy, \\ Instituto de Geología y Minería, Avda. Bolivia 1661, 5100, Jujuy, Argentina. \\ bcoira2015@gmail.com \\ 3 Institute of Earth and Environmental Science, Potsdam University, Karl-Liebknecht-Str. 24-25, 14476 Potsdam-Golm, Germany. \\ Christina.Guenter@geo.uni-potsdam.de \\ ${ }_{4}$ Instituto de Geociências, Universidade de São Paulo, rua do Lago 562, Cidade Universitária, São Paulo, CEP 05508-080, SP, Brasil. \\ hulbrich@usp.br \\ *Corresponding author: claracisterna@csnat.unt.edu.ar
}

\begin{abstract}
This study is focused on the analysis of volcanic deposits that crop out at the middle portion of the Las Planchadas range, northern part of the Famatina System in Argentina. These volcanic rocks are records of an Ordovician effusive basaltic volcanism that took place under subaqueous marine conditions. Along the study area crop out an Arenigian volcanic and volcaniclastic rocks succession with massive and autoclastic lavas, hyaloclastites of basaltic composition and volcaniclastic sandstones and mudstones. Large volumes of the volcanic deposits were strongly affected by fragmentation processes during their subaqueous emplacement and in situ accumulated as basaltic breccias. The same volcanic-volcaniclastic association crops out to the south of the Las Planchadas range, forming a basaltic belt with similar characteristics. The geochemical features of the basalts are compatible with depleted mid-ocean ridge basalt (MORB)like source for the magma, with contribution of subducted related components such as water rich marine hemipelagic sediments, compatible with a back arc geotectonic setting developed along the northern part of the Famatina System during the Arenigian.
\end{abstract}

Keywords: Tholeiitic basalts, Syn-eruptive Hyaloclastic deposits, Ordovician, Famatina belt.

RESUMEN. Basaltos toleíticos arenigianos en la cuenca ordovícica famatiniana, noroeste de Argentina: condiciones de emplazamiento y su implicancia tectónica. El presente trabajo se enfoca en el análisis de los depósitos volcánicos que afloran en el tramo medio de la sierra de Las Planchadas, norte del Sistema de Famatina, Argentina. Estas rocas representan un registro completo del volcanismo ordovícico, correspondiente a efusiones basálticas emplazadas en un ambiente submarino. En la zona estudiada aflora una sucesión volcánica-volcanoclástica representada por lavas macizas y autoclásticas de composición basáltica, hialoclastitas basálticas, psamitas y pelitas volcanoclástica. Extensos volúmenes de estos depósitos fueron afectados fuertemente por procesos de fragmentación durante su emplazamiento subácueo, acumulándose in situ como brechas basálticas. Asociaciones volcánicas-volcanoclástica con idénticas características también afloran hacia el sur, en la misma sierra de Las Planchadas, y forman un cinturón volcánico de basaltos. Las características geoquímicas de estas volcanitas son comparables con basaltos empobrecidos, originados en zonas de dorsales oceánicas (MORB) y con componentes propios de subducción, como la participación de sedimentos hemipelágicos ricos en agua. Estas características son indicativas de un ambiente tectónico de retroarco ligado a la evolución del tramo norte del Sistema de Famatina durante el Arenigiano. 


\section{Introduction}

The studies on the ancient volcanic-volcaniclastic subaqueous rocks sequences carried out over the last decade, have been critical in reconstructing eruptive and depositional processes related to the evolution of many orogenic belts (e.g., Brown et al., 2002; Busby et al., 2006; White, 2000). In the analysis of ancient successions of basaltic flows and associated volcaniclastic deposits emplaced in subaqueous environments, the works of White and Busby-Spera (1987), Templeton and Hanson (2003) and Caroff et al. (2009) among others, have provided substantial elements on the basis of field studies, analysis of structures and textures, for the understanding of the eruptive and depositional processes that controlled their formation. The study of Ordovician volcanic rock sequences along the Puna and the Famatina System (Northwestern Argentina) is the key to define their evolving tectonic setting at that time. In recent years these rocks sequences has been the subject of several studies (e.g., Koukharsky et al., 1996; Coira, 2008; Coira et al., 1999, 2002, 2009; Viramonte et al., 2005).

The Famatina System sensu Petersen and Leanza (1953) comprise a set of ranges extending north-south approximately between $27^{\circ}$ and $31^{\circ} \mathrm{S}$, along the La Rioja and Catamarca provinces. It extends between the Precordillera (northern portion)Cordillera Frontal to the west and the Sierras Pampeanas to the east. The Famatina System is composed by a nearly $3,000 \mathrm{~m}$ thick rock sequence including Late Cambrian to Tremadocian carbonates and siliciclastic rocks, the Arenigian to Llanvirnian? volcanic-sedimentary deposits, and several Early Ordovician arc-related intrusives. These units have been studied by several authors (synthesis have been published in Aceñolaza et al., 1996, Mángano and Buatois, 1996; Saavedra et al., 1998; Astini, 1999; Mángano et al., 2003; among others), suggesting different tectonic setting interpretations. At the northern portion of the Famatina System, along the Las Planchadas and Narváez ranges (Fig. 1), the most voluminous volcanic and volcaniclastic deposits of proved Arenigian age are exposed (Turner, 1967; Cisterna et al., 2010a, b). The study of these volcanic rock sequences may be one of the keys to understand the evolution of the Famatinian terrains as a portion of the western margin of the Gondwana.
This research documents the lavas and syneruptive products of an Arenigian basaltic volcanism occurred in a subaqueous environment. It develops large and well exposed records along Las Planchadas range (north of the Famatina System, northwestern Argentina, Fig. 1). The study of these deposits was made pointing on (i) the existence of several wellpreserved outcrops of basalts displaying characteristic features of an ancient volcanism emplaced in a submarine environment, including well-developed hyaloclastic facies and spatially related to the lavas. (ii) The possibility to relate the studied basalts with other volcanic deposits that crop out in the same geological context and display petrographical and chemical similarities. (iii) To interpret the geodynamic evolution of the Ordovician volcanic belts, at the north portion of the Famatina System as a piece of the Puna - Famatina Belt in the regional context of the Southern Central Andes.

\section{Regional geotectonic interpretations and stratigraphic framework}

The tectonic setting of the Famatina System during the Early Palaeozoic has been a matter of debate during the recent years. While petrologic studies consider this belt as being built on the western Gondwana margin, on the other hand paleomagnetic and biogeographical studies (Conti et al., 1996; Astini and Benedetto, 1996; Benedetto, 1998; Rapalini et al., 1999) point to a parauthochthonous or allochthonous intra Iapetus island arc system. The island arc volcanic setting for the Famatina System (located in the central domain of the Famatina Belt) was initially suggested by Aceñolaza and Tosselli (1984). Subsequently, some authors have favored a back arc setting for that belt on petrological basis (Mannheim, 1993; Clemens, 1993; Toselli et al., 1996). Others, analyzing the stratigraphic and sedimentological records, have indicated an intra-arc basin evolution (Mangano and Buatois, 1996; Cisterna et al., 2010a). Isotopic and geochemical studies on Famatina Early Ordovician granitoids documented the evolution of that magmatic belt on a thickened continental crust (Pankhurst et al., 2000), instead of a genesis under an island arc regime. The extension of this magmatic belt northward in the Puna magmatic belts (Fig. 1) has been postulated by Coira (1975, 1979), Coira et al. (1982), Ramos (1988), Conti et al. (1996) and Cisterna et al. (2010b). 


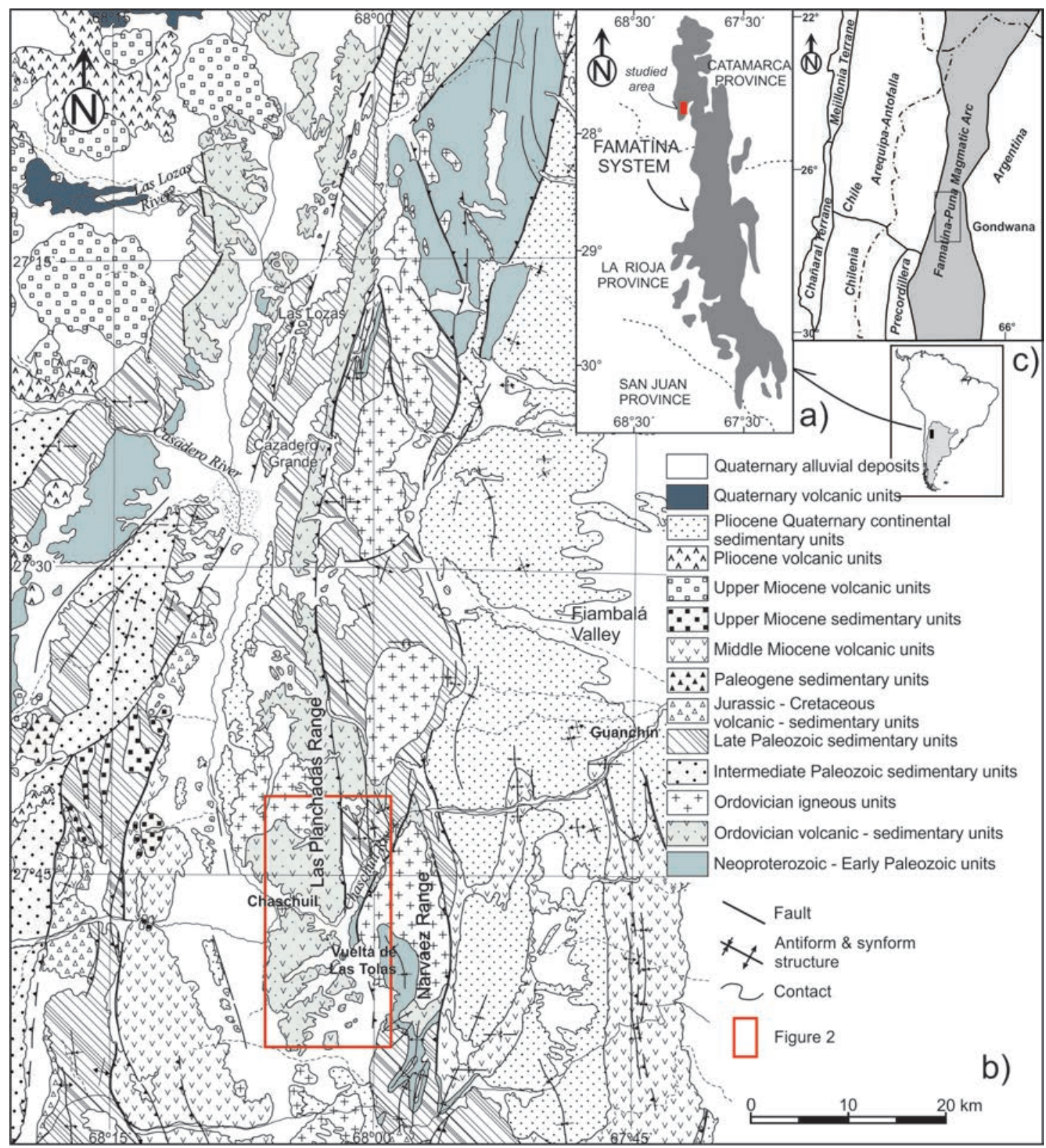

FIG. 1. a. Geological setting of the Famatina-Puna Belt; b. Geological map of the northern Famatina System; c. Regional context of the Famatina-Puna Magmatic Arc.

The Ordovician rocks in the northern portion of the Famatina System comprise Tremadocian and Arenigian volcanic-sedimentary successions. The Tremadocian rocks (Cisterna et al., 2010b) are intruded by the Las Angosturas Granodiorite (Cisterna, 1994 ) with an $\mathrm{U} / \mathrm{Pb}$ age of $485 \pm 7 \mathrm{My}$ (Rubiolo et al., 2002). Nevertheless, the most extensive deposits are represented by the Arenigian succession (Suri Formation, Harrington and Leanza, 1957; and Las Planchadas Formation, Turner, 1958) mainly exposed in the Las Planchadas range (Fig. 2).

To the south of the Las Planchadas range (Chaschuil area) the Arenigian succession is composed by dominant volcaniclastic lithofacies represented by 


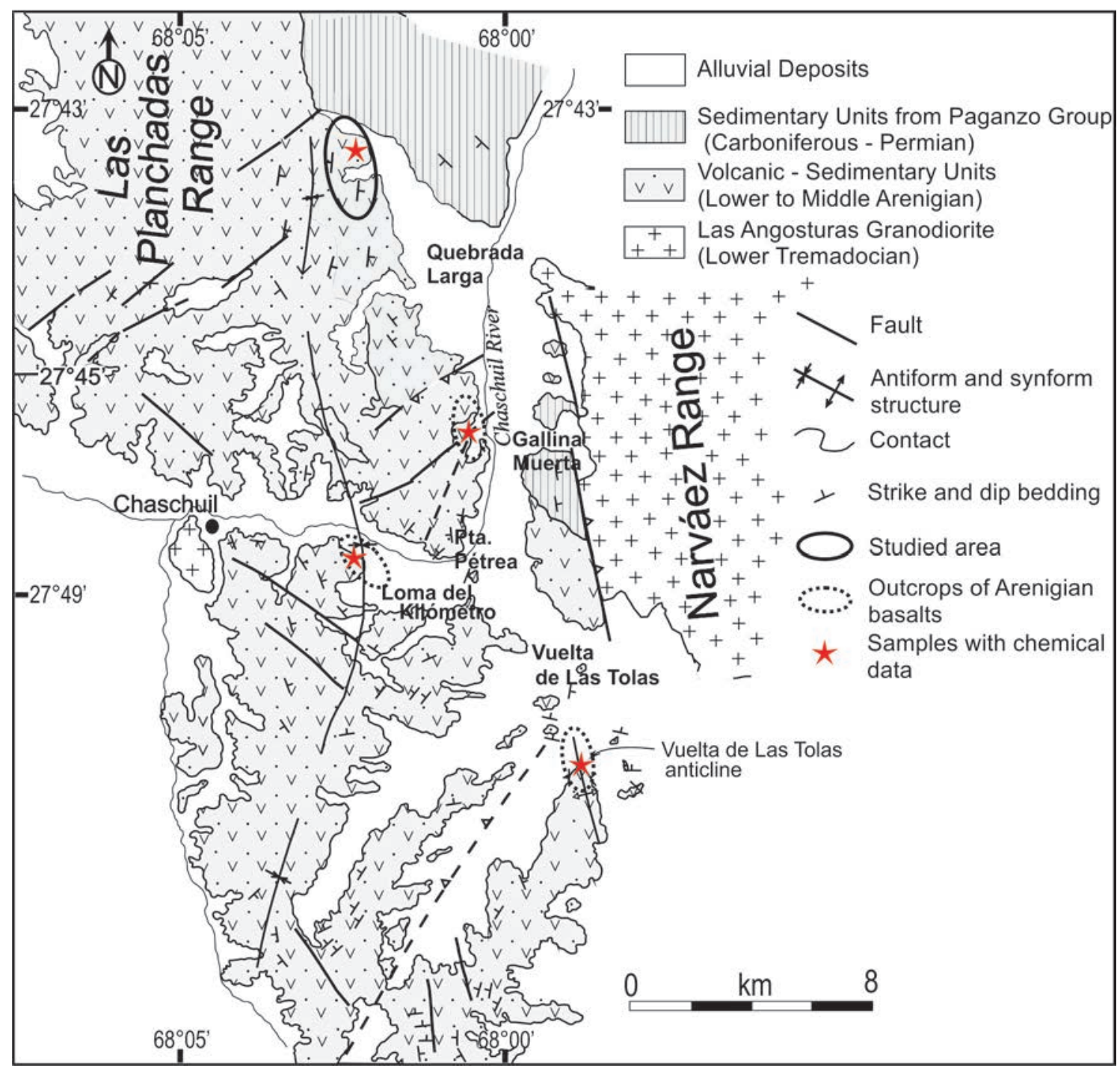

FIG. 2. Map of middle to southern portion of the Las Planchadas range and north of the Narváez range.

volcaniclastic debris flows, turbidity currents and minor resedimented syn-eruptive pyroclastic deposits and lavas (Cisterna and Coira, 2014). At the upper portions, the rock sequence is represented by a volcanogenic sedimentary lithofacies with fossiliferous levels (Mángano and Buatois, 1997). The association of a brachiopod- rich fauna associated with trilobites and conodonts in the pelitic levels allows to assign this unit to the Arenigian (Albanessi and Vaccari, 1994; Benedetto, 1994; Vaccari and Waisfeld, 1994).
At the central portion of the Las Planchadas range (Quebrada Larga-de La Gallina), large outcrops of the Arenigian deposits are mainly composed by basaltic, andesitic and dacitic lavas, with significant volumes of lava-derived clastic deposits (Figs. 2 and 3), produced by quench fragmentation and gravitational collapse of lava deposits (Cisterna et al., 2010a; Slavutsky, 2009). The upper levels of these deposits display volcaniclastic breccias, tuffs and lapilli beds, intercalated with volcanogenic fossiliferous facies, of Arenigian age (Cisterna et 


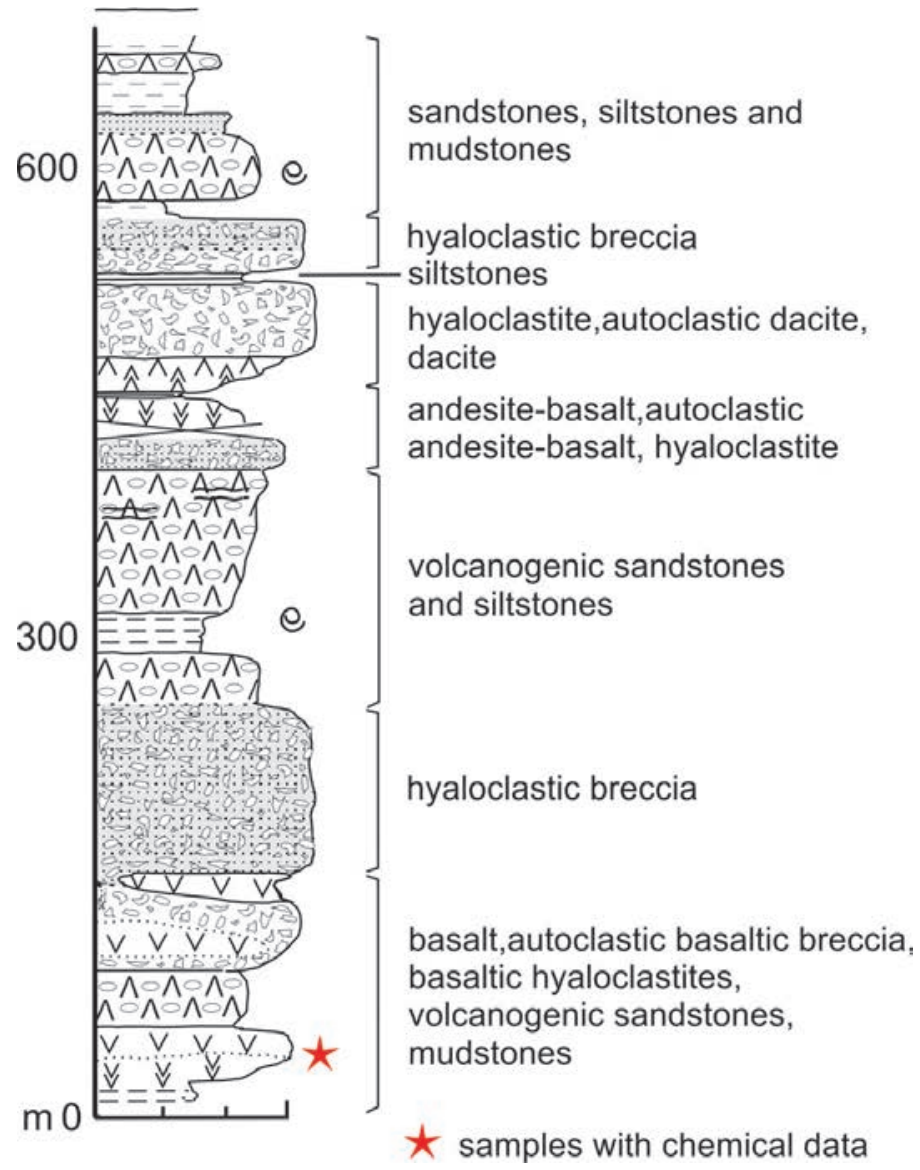

FIG. 3. Generalized stratigraphic section of the Arenigian volcanic deposits cropping out at the Las Planchadas range. The studied succession is part of the lower portion of this column.

al., 2010a). The studied succession represents the lower level of those deposits and the most basic ones.

The Ordovician volcanic successions are covered, in unconformity, by thick Late Paleozoic siliciclastic continental units (Turner, 1967). These sedimentary deposits were defined as the Agua Colorada and Patquía formations and were assigned to the Carboniferous and Permian, respectively (Turner, 1960; Cuerda, 1965).

\section{Internal stratigraphy and lithofacies descriptions at the basaltic members}

The present study was focused on well preserved volcanic deposits (nearly $5 \mathrm{~km}^{2}$ ) that crop out at the middle portion of the Las Planchadas range (Figs. 2 and 4a). They bring together the different facies that characterize the Arenigian volcanic and volcaniclastic deposits along the Las Planchadas range (Quebrada de La Gallina, Vuelta de Las Tolas and Chaschuil, Figs. 2 and 5). This Ordovician stratigraphic succession builds up a synclinal structure, whose axis is subhorizontal, with a north-south trend. The field mapping shows that the Ordovician deposits certainly form a sequence without tectonic repetition. The base of the section is poorly exposed to the east, where locally an irregular contact can be observed between the basalt and a yellow siltstone (Fig. 4b). The top of the section has volcaniclastic facies (sandstones and mudstones), laterally equivalent to the fossiliferous volcaniclastic sandstones containing an Arenigian brachiopod fauna (Cisterna et al., 2010a) cropping out along the Quebrada Larga-de La Gallina (to the south of the study area) (Figs. 2 and 3). 


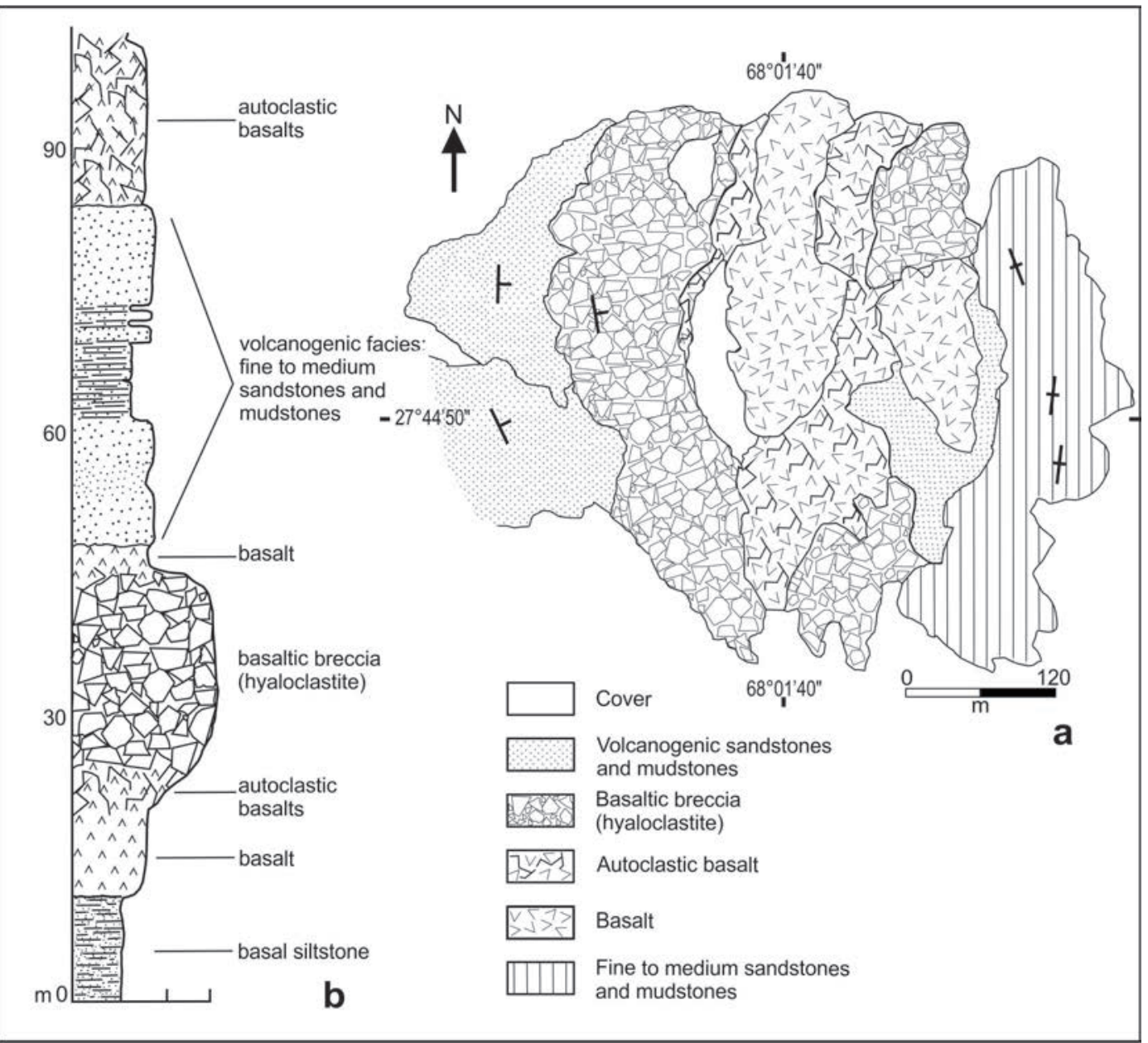

FIG. 4. a. Map of the basaltic volcaniclastic deposits studied; b. Schematic log showing the internal organization of the analyzed section.

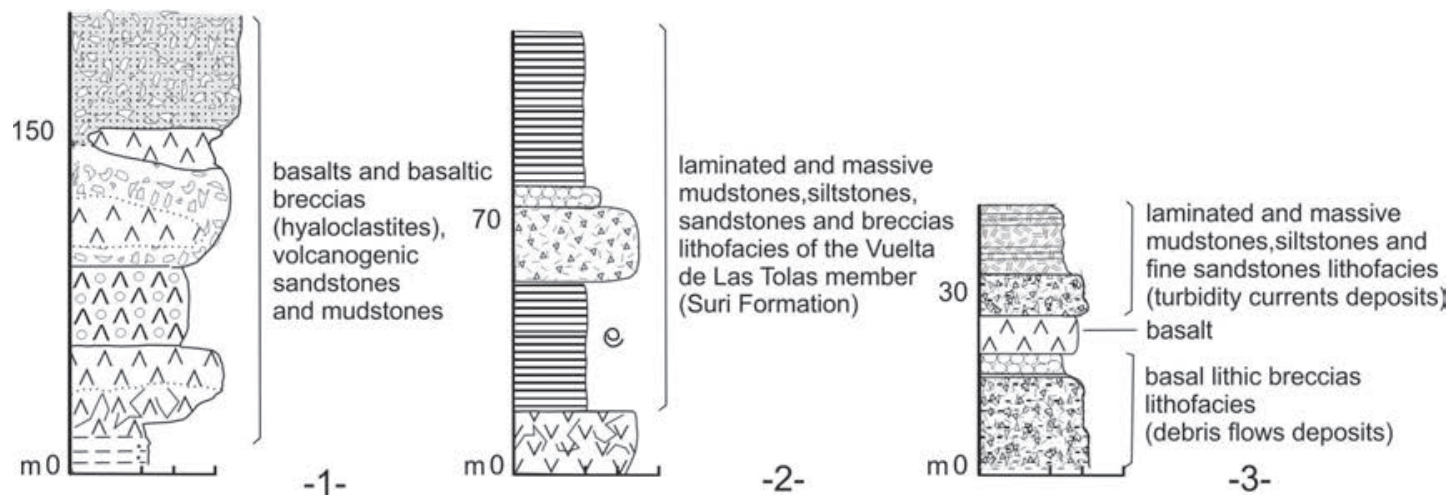

FIG. 5. Generalized comparative logs of the 1. Lower portion of the Quebrada Larga-La Gallina section (simplified from Cisterna et al., 2010a); 2. Lower portion of the Vuelta de Las Tolas section; 3. Intermediate portion along the Chaschuil section (simplified from Cisterna and Coira, 2014). 
Although the majority of the studied rocks have been affected by hydrothermal and low grade metamorphic processes, it is still possible to recognize their primary petrographic characteristics and to analyze their chemical signature on the basis of immobile elements.

\subsection{Facies descriptions}

\subsubsection{Basaltic facies}

Basalts crop out as lenticular or tabular bodies, varying between $2.5-10 \mathrm{~m}$ thick and usually showing transitional relationships to the autoclastic facies (Fig. 4b). They are greenish black, generally massive and fine-grained with a groundmass of varying texture and crystallinity. By sectors, basalts show a flow foliated structure and irregular vesicles $(2 \mathrm{~mm}-2.5 \mathrm{~cm})$.

Generally the basalts are porphyritic, sometimes glomerophyric, and phenocrysts (5-10\%) are mostly plagioclase (1-3 mm) (27\%) and lesser amounts augite $(1 \mathrm{~mm})(1.5 \%)$. The phenocrysts may be fractured, especially the plagioclase which is corroded and frequently shows numerous glass inclusions (Figs. 6a, b). The scarce augite phenocrysts (Fig. 6d) are euhedral, while augite microphenocrysts are mostly equant, and may show a compositional zonation, almost always overgrown by tremolite (Figs. 6e and 7a). Olivine also forms microphenocrysts, frequently replaced by pyroxene and/or amphibole and may be fragmented (Figs. 6e, f), displaying variable degrees of alteration to iddingsite and carbonate. The groundmass is grey to greenish grey; its texture is generally pilotaxitic and rarely ophitic or subophitic (Fig. 6c). Besides glass, which is commonly present, the groundmass constituents are plagioclase microlites, augite, olivine and abundant opaque minerals. The microlites are weakly to moderately align; some are deflected around the phenocrysts and show morphologies such as swallow-tail terminations. The glass may be either fresh or altered to palagonite (Fig. 7b). Vesicles, which may be flow-aligned, are filled by calcite, quartz and/or chlorite. Some round vesicles are filled by quartz (Fig. 7c).

\subsubsection{Autoclastic basaltic facies}

They are composed by highly fractured basalts, developing jigsaw-fit textures (Fig. 8a). The blocky fragments are larger than $3 \mathrm{~cm}$, most of them have curviplanar fracture surfaces; no chilled margins are observed. The contacts may be sharp or gradational between these deposits and the coherent basalts.

\subsubsection{Hyaloclastic basaltic facies}

They form deposits up to $60 \mathrm{~m}$ thick, in transitional or sharp contact related to the autoclastic facies and massive basalts. The hyaloclastites within the basalts are commonly observed as tabular bodies less than $1 \mathrm{~m}$ in thickness (Fig. 8a). Hyaloclastites are poorly sorted monomictic basaltic breccias, with randomly oriented clasts. The shapes vary between flow foliated slabs with jagged ends, and ragged or blocky clasts with curviplanar surfaces (Fig. 8b). Besides, they may also display a jigsaw texture. The clasts may develop quenched margins and glassy rims. Their size varies in different sectors (from less than one $\mathrm{mm}$ up to $50 \mathrm{~cm}$ ), usually larger near the massive lavas. The groundmass is composed of glassy particles and phenocryst fragments (plagioclase), carbonate and palagonite. The vesicles are irregular and may show flow alignment (Fig. 8b). The clasts are hyaloclastic basalts showing different structures, as described below (Figs. 9a, b and c). The most frequent have a vitric groundmass, sometimes altered to palagonite, with thin plagioclase laths in a pilotaxic groundmass and elongated or subrounded vesicles, aligned parallel to the long axis of the clasts, and filled by carbonate or chlorite (Figs. 9b, c). The basaltic clasts may also be rounded and subrounded, with quenched margins (Figs. 9a, d, e and 8a) and a groundmass composed by glass or oxidized glass, feldspar microlites and vesicles filled by carbonate, chlorite and quartz; phenocrysts, sometimes fractured, are plagioclase and augite. Plagioclase may be euhedral or display large corroded crystals (Figs. 10b, c). They frequently show zonation and numerous glass inclusions (Fig. 10d). The augite and olivine (as microphenocrysts) are overgrown by amphiboles (Fig. 7a). Other types of clasts are rounded and highly vesiculated basalts (Fig. 9f).

\section{Geochemistry}

\subsection{Methodology}

All geochemical analyses were performed on selected samples, after close petrographic observations. The localities of each sample can be seen at the figure 2 and they correspond to basalts (MQL3, 

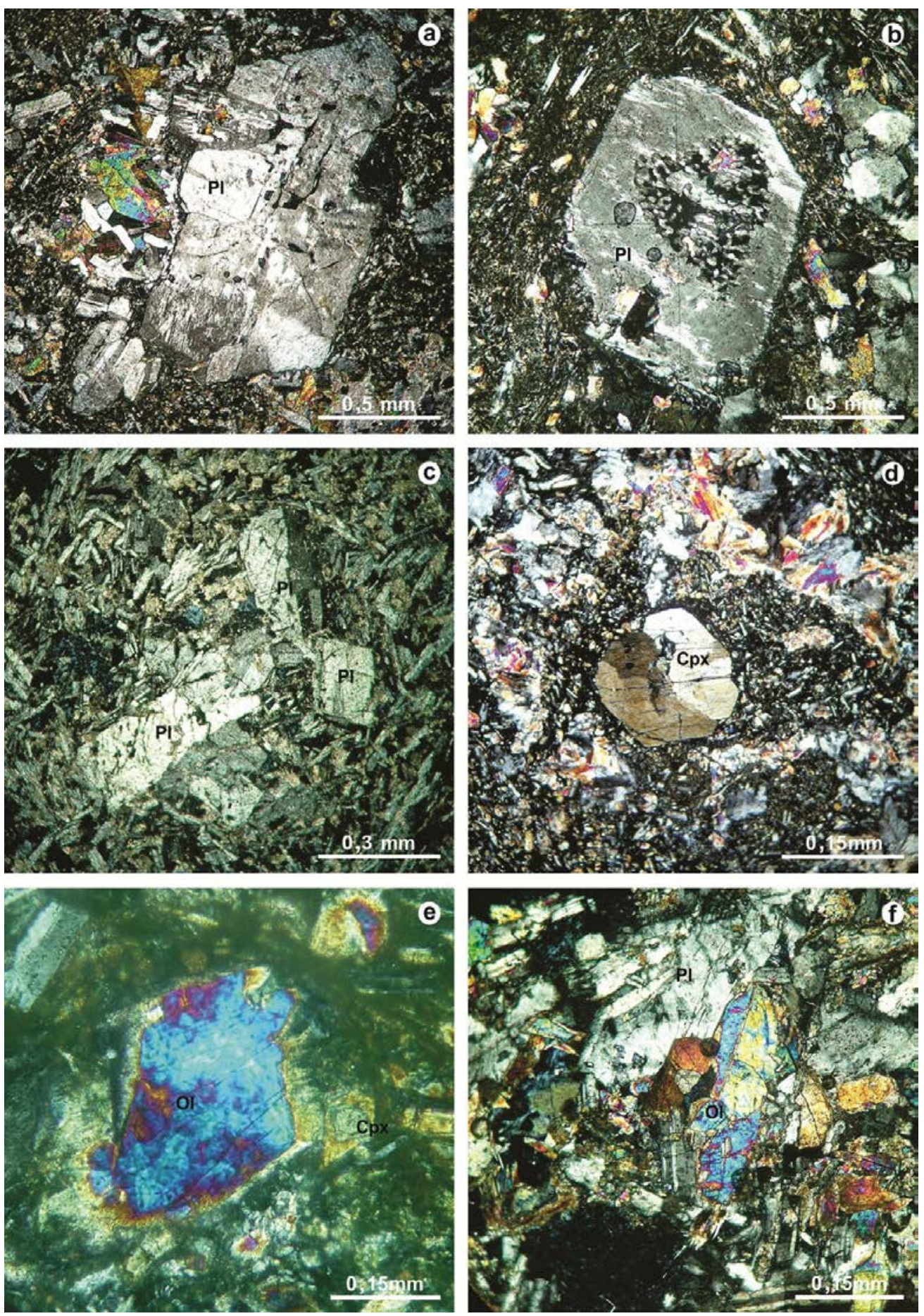

FIG. 6. Basalts showing: a. Plagioclase phenocryst showing resorbed zones near the core and fractures; b. Extensive glass inclusions in the core of the plagioclase phenocryst; c. Plagioclase phenocrysts developing glomerophyric clots and pilotaxitic groundmass; d. Equant augite microphenocryst, euhedral and zoned in a groundmass showing abundant devitrified glass; e-f. Olivine microphenocrysts partially resorbed and as fragmental grains. Crossed polarized light in all photomicrographs (Mineral abbreviations as suggested by Kretz, 1983). 

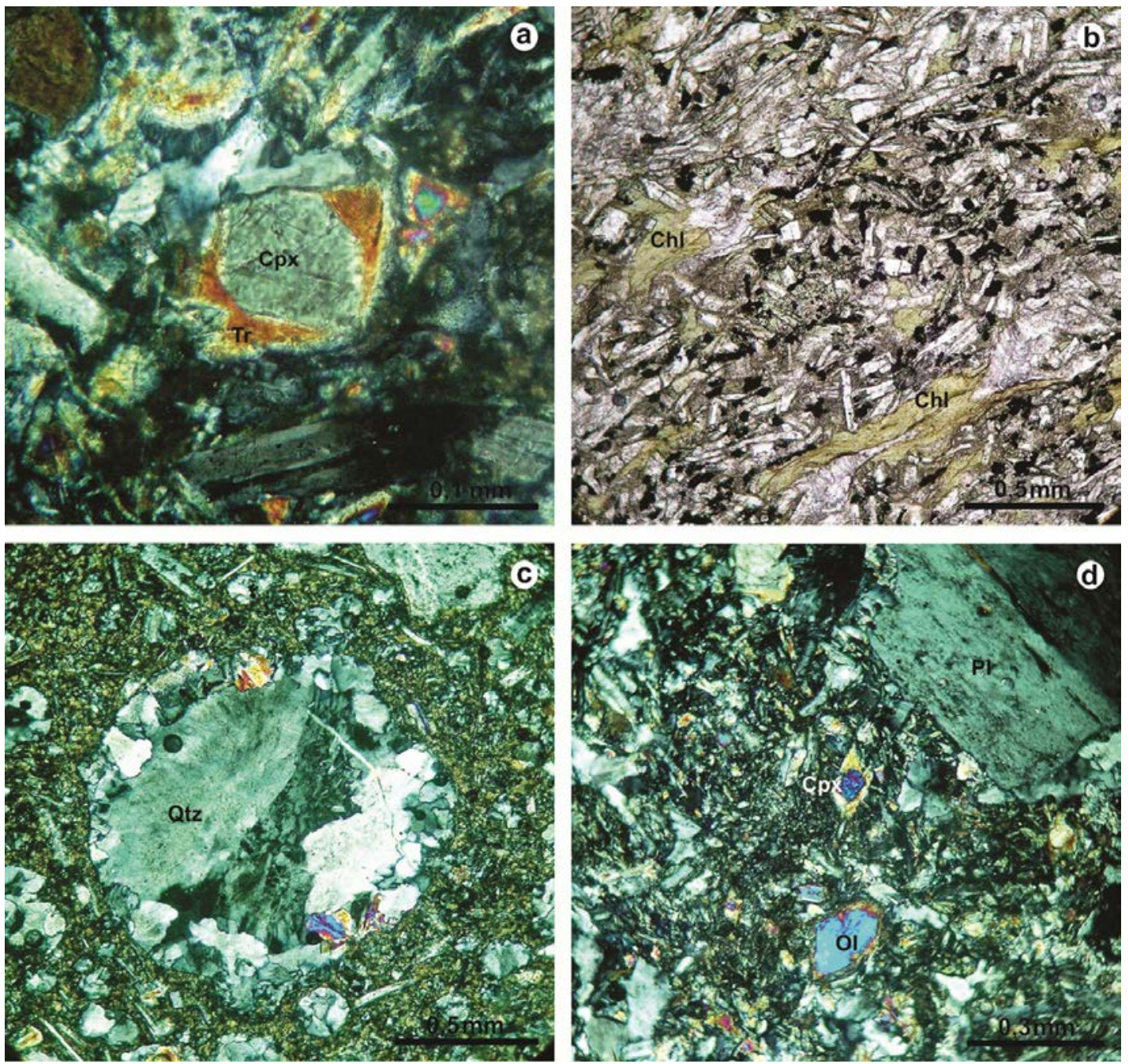

FIG. 7. Photomicrographs showing a. Augite overgrown by tremolite. Crossed polarized light. (Mineral abbreviations as suggested by Kretz, 1983); b. Plagioclase microliths, magnetite and palagonite replacing the glass groundmass. Plane polarized light; c. Rounded vesicle filled by quartz. Crossed polarized light; d. Basaltic groundmass showing, besides glass, plagioclase microlites, augite, olivine and abundant opaque minerals. Crossed polarized light.

MQL5, NQL1, NQL5, NQL18, NQL19, PC10, VT10, T5 and CG147) and basaltic hyaloclastites (NQL17, PC13, B11). The compositions of the whole-rock samples, including major, minor and trace elements were determined by wavelength dispersive X-ray fluorescence spectrometry (WD-XRFS). Rare earth element (REE) analyses were collected using a VARIAN Vista MPX ICP-OES (inductively coupled plasma-optical emission spectrometry). All the previews analyses were performed at either the GFZ in Potsdam or at the laboratories of the Institute of
Earth and Environmental Science, University of Potsdam, Germany.

The CG-147, PC10, VT10 and T5 samples were analyzed at the Chemical Laboratory of the Institute of Geosciences (Sao Paulo University) where major oxides and trace elements were determined by wavelength-dispersive X-ray fluorescence spectrometry (WD-XRFS) on fused glass discs using a Philips 9PW2400 spectrometer. Trace elements, including REE, were determined by inductivelycoupled plasma mass spectrometry (ICP-MS). 

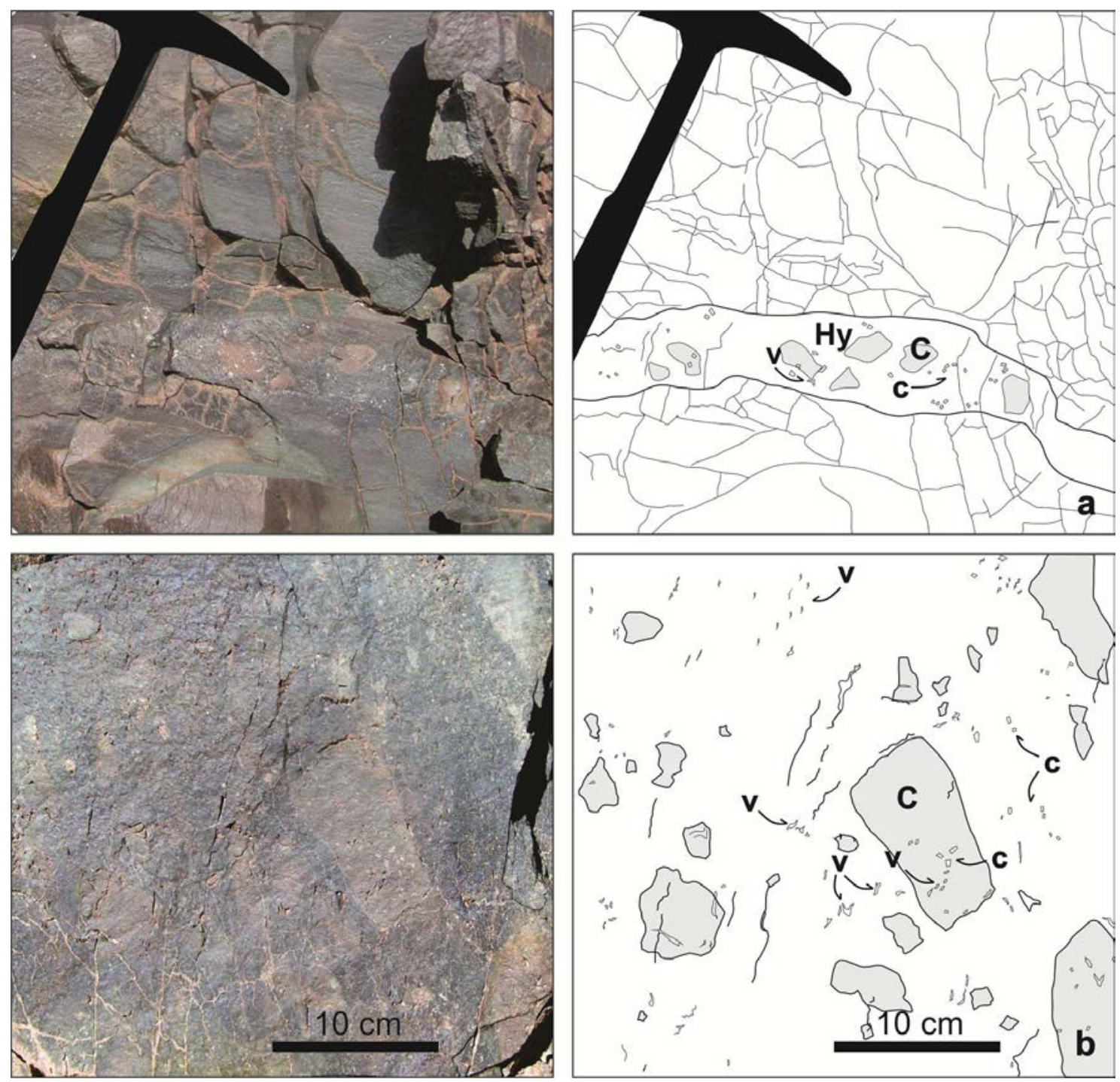

FIG. 8. a. Autoclastic basalt showing a jigsaw texture and a dyke of groundmass rich in in situ hyaloclastite. Clasts in the hyaloclastite have curviplanar margins and are oxidized. Vesicles are filled by carbonate. Schematic graph of the autoclastic basalt and the hyaloclastite (Hy). (C: clasts, c: crystalloclasts, v: vesicles); b. Monomictic hyaloclastite with clasts of different size and shape. They are blocky and the margins are not quenched. Clasts and groundmass contain abundant, very irregular vesicles. Schematic graph showing the monomictic hyaloclastite (C: clasts, c: crystalloclasts, v: vesicles).

\subsection{Major and trace elements}

Samples of basalts of the study area were analyzed alongside those of correlated basalts that crop out to the south (Quebrada Larga, Quebrada de la Gallina, Vuelta de Las Tolas and Chaschuil) (Fig. 2), in order to find out if they show compositional affinities that link them to the same magmatic event. The samples include hyaloclastic basalts (from the Quebrada Larga) showing some variations regarding to the massive basalts, due to the presence of siliceous aggregates along the fractures. Results are shown in table 1.

Most of the samples show a relatively high LOI, so we have opted for their characterization by the use of immobile elements. For classification, the $\mathrm{Zr} /$ $\mathrm{TiO}_{2}$ versus $\mathrm{SiO}_{2}$ diagram of Winchester and Floyd 

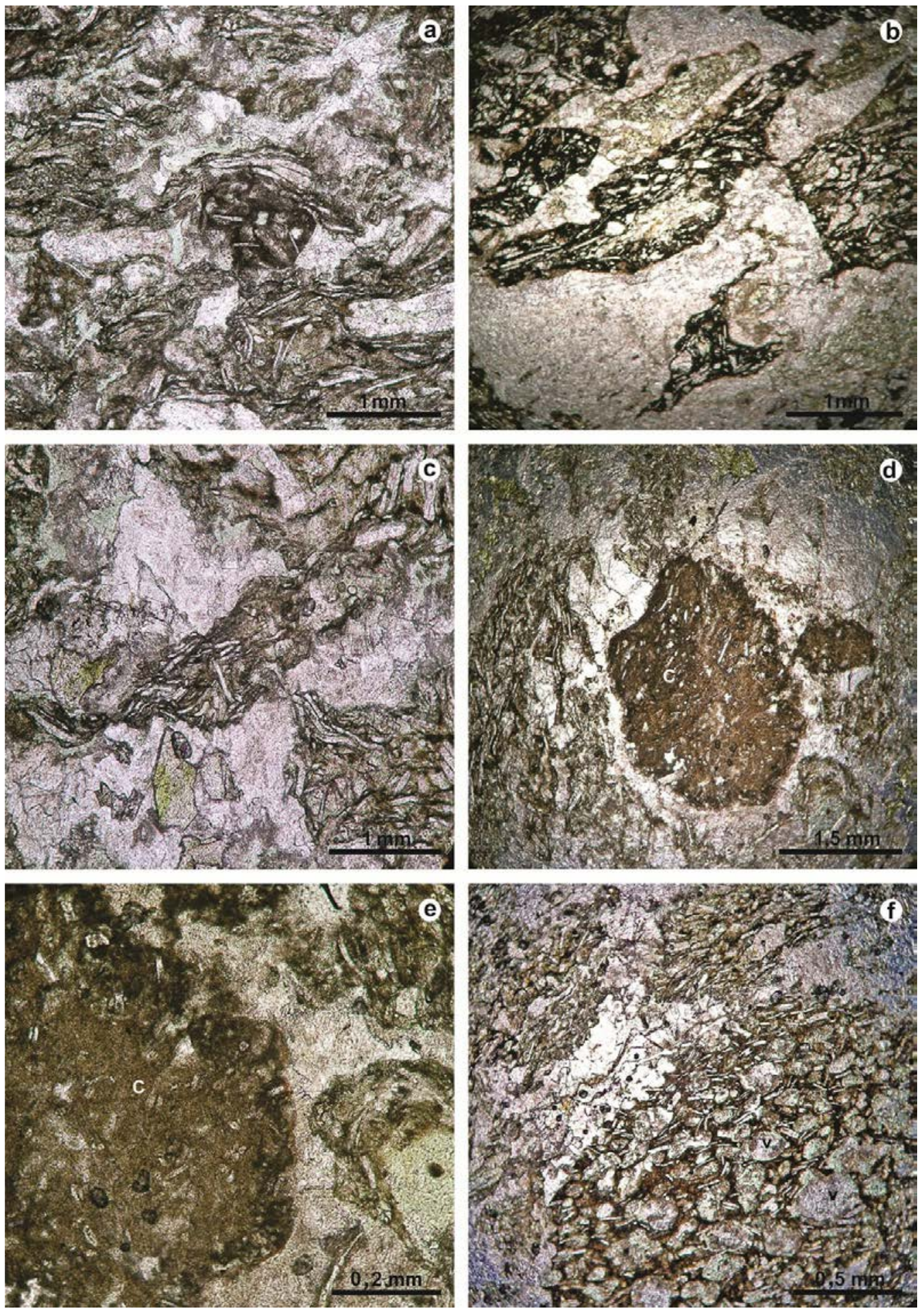

FIG. 9. Basaltic hyaloclastites showing at the microscope a. Small equant basaltic clast together with flow foliated clasts; b-c. Elongated clasts, generally with jagged ends or ragged. Calcite is abundant in the groundmass; d. Rounded basaltic clast with quenched margins, the detail (e) showing the oxidized glass groundmass; $\mathbf{f}$. Rounded basaltic clast with abundant rounded vesicles filled by carbonate, chlorite and quartz. Plane polarized light in all photomicrographs. 

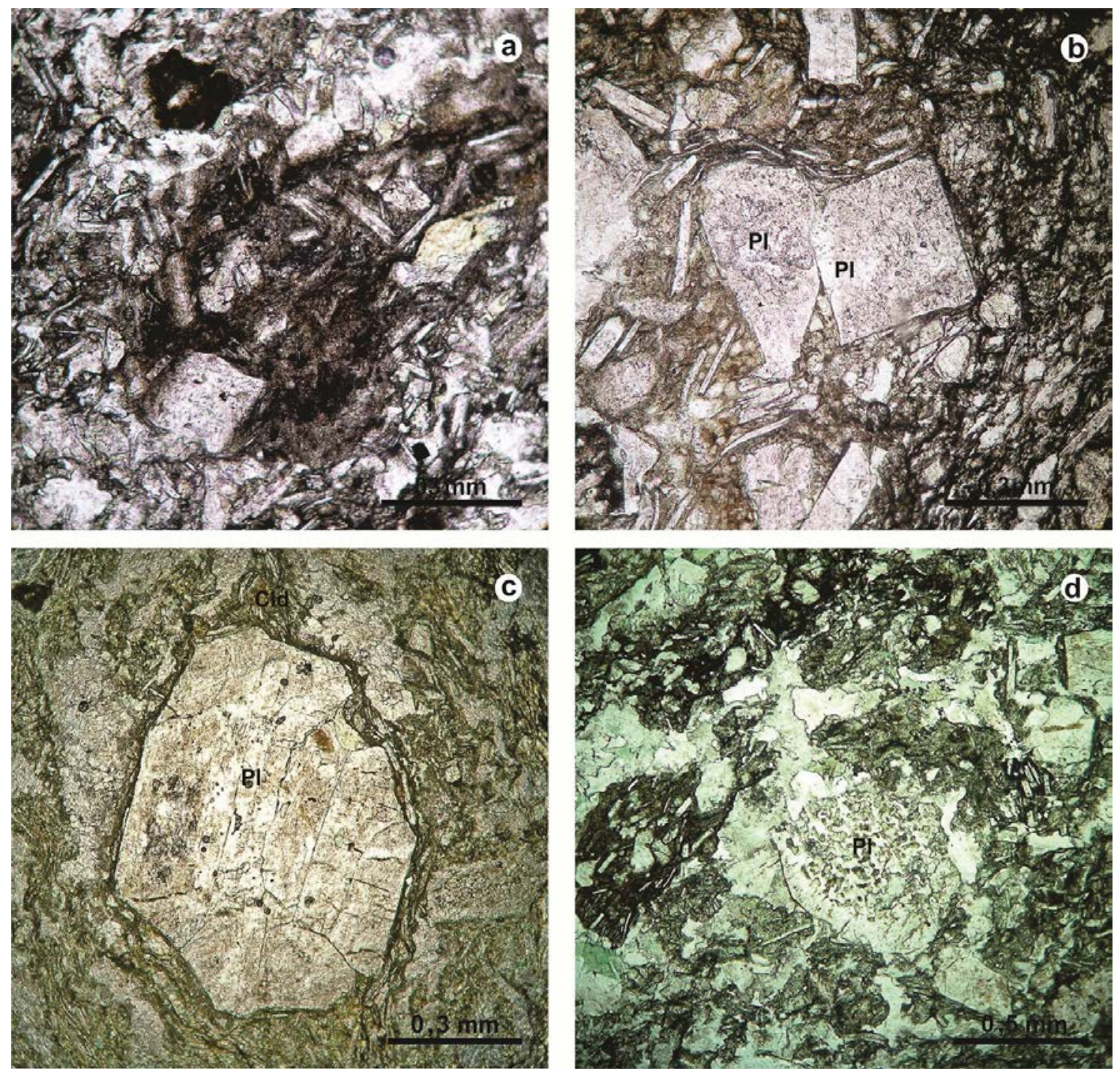

FIG. 10. Photomicrographs showing a. Small basaltic clast with glass groundmass, euhedral plagioclase microphenocryst and microliths; b-c. Euhedral and partially corroded crystalloclasts of plagioclase; d. Plagioclase crystalloclast showing glass inclusions in the core. Plane polarized light in all photomicrographs.

(1977) has been applied, indicating that they are geochemically basalts (Fig. 11a). The $\mathrm{FeO} * \mathrm{MgO}$ versus $\mathrm{SiO}_{2}$ diagram (Miyashiro, 1974) confirms the tholeiitic character of the basalts like the $\mathrm{Zr} / \mathrm{Y}$ relation (Barrett and MacLean, 1999) (Figs. 11b, c). The hyaloclastic basalts are characterized by the lowest content of $\mathrm{Fe}_{2} \mathrm{O}_{3}, \mathrm{MgO}$ and $\mathrm{Al}_{2} \mathrm{O}_{3}$ (Table 1) and the enrichment in $\mathrm{SiO}_{2}$ (average $69.05 \%$ and $47.40 \%$ in massive basalts) that is related to the hydrothermal alteration, so these data are not used.
The analyzed basalts display low Mg-numbers $\left[\mathrm{Mg} \#=100 \times \mathrm{Mg} /\left(\mathrm{Mg}+\mathrm{Fe}^{+}\right)\right]$ranging from 56 to 36 (Table 1), low Ni (20-63 ppm), Cr (85-199 $\mathrm{ppm}), \mathrm{MgO}(3.94-7.45 \mathrm{wt} \%)$ and relatively high LOI (8.34-3.38wt\%). Likewise they are low-Ti on the basis of their Ti/Y ratios=213-278 $(\mathrm{Ti} / \mathrm{Y}$ <500: low-Ti basalts, c.f. Cummins et al., 1992) and $\mathrm{TiO}_{2}=0.76-0.96 \%\left(\mathrm{TiO}_{2} \mathrm{wt} \%<2.5:\right.$ low-Ti basalts, c.f. Cummins et al., 1992). They have an average of $\mathrm{FeOt} / \mathrm{TiO}_{2}=11.89$ and the trace elements 


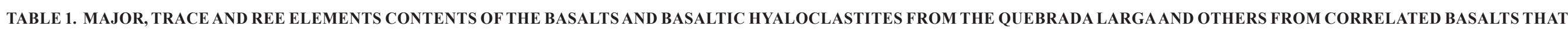
CROP OUT TO THE SOUTH EASTERN AND SOUTH OF THE AREA.

\begin{tabular}{|c|c|c|c|c|c|c|c|c|c|c|c|c|c|}
\hline \multirow{2}{*}{$\begin{array}{c}\text { Location } \\
\text { Sample }\end{array}$} & \multicolumn{7}{|c|}{ Northern Quebrada Larga } & \multicolumn{2}{|c|}{ Southeastern Quebrada Larga } & \multicolumn{2}{|c|}{ Quebrada de La Gallina } & \multirow{3}{*}{$\begin{array}{c}\text { Vuelta de Las Tolas } \\
\text { T-5* } \\
\text { basalt }\end{array}$} & \multirow{3}{*}{$\begin{array}{c}\text { Chaschuil } \\
\text { CG-147* } \\
\text { basalt }\end{array}$} \\
\hline & NQL1 & NQL5 & NQL17 & NQL18 & NQL19 & MQL3 & MQL5 & PC-10* & PC-13 & B11 & VT-10* & & \\
\hline & basalt & basalt & $\begin{array}{c}\text { basaltic } \\
\text { hyaloclastite }\end{array}$ & basalt & basalt & basalt & basalt & basalt & $\begin{array}{c}\text { pillow basaltic } \\
\text { breccia }\end{array}$ & $\begin{array}{c}\text { basaltic } \\
\text { hyaloclastite }\end{array}$ & basalt & & \\
\hline Location & $\begin{array}{l}27^{\circ} 44^{\prime} 58.58^{\prime \prime} \\
68^{\circ} 01^{\prime} 37.85^{\prime}\end{array}$ & $\begin{array}{l}27^{\circ} 44^{\prime} 56.88^{\prime \prime} \\
68^{\circ} 01^{\prime} 38.93^{\prime \prime}\end{array}$ & $\begin{array}{l}27^{\circ} 44^{\prime} 45.89^{\prime \prime} \\
68^{\circ} 01^{\prime} 47.42^{\prime}\end{array}$ & $\begin{array}{l}27^{\circ} 44^{\prime} 50.69^{\prime \prime} \\
68^{\circ} 01^{\prime} 44.18^{\prime \prime}\end{array}$ & $\begin{array}{l}27^{\circ} 44^{\prime} 47.04 " \\
68^{\circ} 01^{\prime} 48.41^{\prime \prime}\end{array}$ & $\begin{array}{l}27^{\circ} 44^{\prime} 29.99^{\prime \prime} \\
68^{\circ} 01^{\prime} 38.84^{\prime \prime}\end{array}$ & $\begin{array}{l}27^{\circ} 44^{\prime} 33.96^{\prime \prime} \\
68^{\circ} 01^{\prime} 41.30^{\prime \prime}\end{array}$ & $\begin{array}{l}27^{\circ} 45^{\prime} 36.37^{\prime \prime} \\
68^{\circ} 01^{\prime} 50.11^{\prime \prime}\end{array}$ & $\begin{array}{l}27^{\circ} 45^{\prime} 42.61^{\prime \prime} \\
68^{\circ} 01^{\prime} 42.07^{\prime}\end{array}$ & $\begin{array}{l}27^{\circ} 46^{\prime} 24.39^{\prime \prime} \\
68^{\circ} 01^{\prime} 38.37^{\prime \prime}\end{array}$ & $\begin{array}{l}27^{\circ} 47^{\prime} 45.68^{\prime \prime} \\
68^{\circ} 01^{\prime} 44.90^{\prime \prime}\end{array}$ & $\begin{array}{l}27^{\circ} 49^{\prime} 23.06^{\prime \prime} \\
68^{\circ} 02^{\prime} 33.84^{\prime \prime}\end{array}$ & $\begin{array}{l}27^{\circ} 47^{\prime} 47.03 " \\
68^{\circ} 03^{\prime} 36.01 "\end{array}$ \\
\hline \multicolumn{14}{|l|}{$\mathrm{wt} \%$} \\
\hline $\mathrm{SiO}_{2}$ & 45.8 & 46.30 & 68.60 & 49.50 & 47.30 & 45.40 & 46.90 & 47.93 & 50.60 & 69.50 & 48.69 & 50.10 & 48.00 \\
\hline $\mathrm{TiO}_{2}$ & 0.92 & 0.96 & 0.25 & 0.78 & 0.93 & 0.81 & 0.78 & 0.96 & 0.83 & 0.20 & 0.90 & 0.76 & 0.79 \\
\hline $\mathrm{Al}_{2} \mathrm{O}_{3}$ & 17.20 & 16.00 & 9.40 & 14.30 & 17.10 & 17.40 & 16.40 & 16.90 & 18.60 & 10.40 & 15.39 & 14.32 & 16.51 \\
\hline $\mathrm{Fe}_{2} \mathrm{O}_{3}$ & 10.48 & 10.62 & 1.13 & 7.68 & 11.16 & 10.80 & 10.46 & 11.07 & 10.24 & 6.59 & 10.64 & 8.28 & 10.69 \\
\hline $\mathrm{MnO}$ & 0.18 & 0.20 & 0.08 & 0.16 & 0.17 & 0.18 & 0.20 & 0.19 & 0.18 & 0.15 & 0.19 & 0.31 & 0.19 \\
\hline $\mathrm{MgO}$ & 7.31 & 7.13 & 0.48 & 5.15 & 7.30 & 6.76 & 7.45 & 5.73 & 5.50 & 2.10 & 5.58 & 3.94 & 6.61 \\
\hline $\mathrm{CaO}$ & 4.94 & 5.63 & 8.24 & 7.28 & 7.68 & 10.50 & 9.10 & 8.20 & 3.31 & 2.71 & 6.82 & 8.66 & 8.26 \\
\hline $\mathrm{Na}_{2} \mathrm{O}$ & 3.50 & 4.99 & 4.88 & 2.13 & 3.73 & 2.75 & 3.59 & 4.65 & 5.58 & 3.49 & 2.96 & 3.59 & 2.58 \\
\hline $\mathrm{K}_{2} \mathrm{O}$ & 1.58 & 0.26 & 0.17 & 4.25 & 0.40 & 0.85 & 0.15 & 0.34 & 1.08 & 1.01 & 1.24 & 0.61 & 2.57 \\
\hline $\mathrm{P}_{2} \mathrm{O}_{5}$ & 0.21 & 0.19 & 0.05 & 0.15 & 0.14 & 0.12 & 0.12 & 0.17 & 0.13 & 0.04 & 0.16 & 0.20 & 0.12 \\
\hline LOI & 7.52 & 7.62 & 6.57 & 8.34 & 3.88 & 4.21 & 4.63 & 3.82 & 3.77 & 3.61 & 7.42 & 7.94 & 3.38 \\
\hline$\# \mathrm{Mg}$ & 55 & 54 & 43 & 54 & 54 & 53 & 56 & 48 & 49 & 36 & 48 & 46 & 52 \\
\hline \multicolumn{14}{|l|}{ ppm } \\
\hline $\mathrm{Rb}$ & 53 & 11 & 10 & 99 & 15 & 24 & 10 & 8 & 36 & 28 & 66 & 34 & 77 \\
\hline $\mathrm{Sr}$ & 109 & 130 & 50 & 103 & 211 & 209 & 129 & 137 & 216 & 35 & 170 & 134 & 307 \\
\hline $\mathrm{Zr}$ & 74 & 71 & 98 & 66 & 62 & 53 & 50 & 78 & 56 & 148 & 83 & 63.8 & 44 \\
\hline $\mathrm{Ba}$ & 294 & 102 & 38 & 488 & 105 & 167 & 51 & 126 & 414 & 242 & 119 & 72 & 313 \\
\hline $\mathrm{Pb}$ & - & - & - & - & - & - & - & 1.99 & - & - & 5.73 & 3.22 & - \\
\hline Th & - & - & - & - & - & - & - & 1.88 & - & - & 1.97 & 1.75 & 2.07 \\
\hline $\mathrm{U}$ & - & - & - & - & - & - & - & 0.46 & - & - & 0.48 & 0.50 & 0.50 \\
\hline $\mathrm{Nb}$ & $<10$ & $<10$ & $<10$ & $<10$ & $<10$ & $1.99 *$ & $1.99 *$ & 3.5 & $2.74 *$ & $<10$ & 1.82 & 2.66 & 1.00 \\
\hline $\mathrm{Cr}$ & 189 & 188 & 56 & 103 & 199 & 165 & 184 & 126 & 163 & 14 & 109 & 85 & 90.2 \\
\hline $\mathrm{Ni}$ & 63 & 58 & 10 & 29 & 62 & 53 & 63 & 26 & 34 & 14 & 35 & 20 & 18 \\
\hline $\mathrm{Sc}$ & 36 & 36 & 10 & 32 & 40 & 35 & 34 & 38 & 39 & 11 & 36 & 30 & 36.6 \\
\hline $\mathrm{V}$ & 230 & 254 & 42 & 203 & 267 & 274 & 261 & 259 & 240 & 27 & 259 & 259 & 294 \\
\hline $\mathrm{Zn}$ & 145 & 107 & 10 & 65 & 80 & 76 & 188 & 91 & 107 & 99 & 86 & 81 & 115 \\
\hline $\mathrm{Hf}$ & - & - & - & - & - & - & - & 1.63 & - & - & 1.77 & 1.68 & 1.38 \\
\hline $\mathrm{Y}$ & 25 & 23 & 23 & 22 & 20 & 18 & 20 & 22 & 18 & 42 & 23 & 19.2 & 18 \\
\hline $\mathrm{La}$ & 12 & 10 & 16 & 9.0 & 7.7 & 6.5 & 6.1 & 10.6 & 14 & 26 & 10 & 9.3 & 8.69 \\
\hline $\mathrm{Ce}$ & 27 & 23 & 36 & 21 & 18 & 15 & 14 & 22.1 & 31 & 54 & 21.2 & 21.7 & 21.2 \\
\hline $\operatorname{Pr}$ & 3.3 & 2.9 & 3.8 & 2.5 & 2.1 & 1.7 & 1.5 & 2.95 & 3.9 & 6.1 & 2.91 & 2.95 & 15.2 \\
\hline $\mathrm{Nd}$ & 16 & 14 & 17 & 12 & 11 & 9.4 & 9.1 & 12.9 & 18 & 26 & 12.6 & 12.9 & 2.83 \\
\hline $\mathrm{Sm}$ & 3.9 & 3.5 & 3.8 & 3.0 & 2.7 & 2.4 & 2.4 & 3.15 & 4.8 & 5.8 & 3.09 & 3.18 & 0.96 \\
\hline $\mathrm{Eu}$ & 1.2 & 1.1 & 0.79 & 0.9 & 0.94 & 0.96 & 0.82 & 1.13 & 0.75 & 1.3 & 0.90 & 0.94 & 2.5 \\
\hline $\mathrm{Gd}$ & 4.1 & 3.7 & 3.6 & 3.2 & 3.1 & 2.7 & 2.7 & 3.48 & 5.7 & 5.8 & 3.41 & 3.62 & 1.43 \\
\hline $\mathrm{Tb}$ & 0.75 & 0.69 & 0.61 & 0.59 & 0.58 & 0.56 & 0.49 & 0.52 & 1.24 & 1.1 & 0.53 & 0.56 & - \\
\hline Dy & 4.0 & 3.7 & 3.8 & 3.3 & 3.2 & 2.8 & 2.8 & 3.27 & 7.8 & 6.2 & 3.33 & 3.3 & - \\
\hline Но & 0.79 & 0.75 & 0.78 & 0.65 & 0.65 & 0.59 & 0.56 & 0.69 & 2.0 & 1.3 & 0.72 & 0.74 & 0.59 \\
\hline Er & 2.4 & 2.2 & 2.4 & 2.0 & 2.0 & 1.7 & 1.7 & 1.89 & 5.6 & 4.0 & 1.95 & 1.97 & - \\
\hline $\mathrm{Tm}$ & 0.50 & 0.50 & 0.50 & 0.50 & 0.50 & 0.50 & 0.50 & 0.28 & 0.87 & 0.62 & 0.30 & 0.3 & - \\
\hline $\mathrm{Yb}$ & 2.3 & 2.1 & 2.5 & 1.9 & 1.9 & 1.7 & 1.6 & 1.8 & 5.4 & 4.0 & 1.92 & 1.88 & - \\
\hline $\mathrm{Lu}$ & 0.50 & 0.50 & 0.50 & 0.50 & 0.50 & 0.50 & 0.50 & 0.27 & 0.76 & 0.61 & 0.28 & 0.28 & 0.265 \\
\hline
\end{tabular}

* Sample/or element analyzed in the Instituto de Geociências, Universidade de São Paulo. 

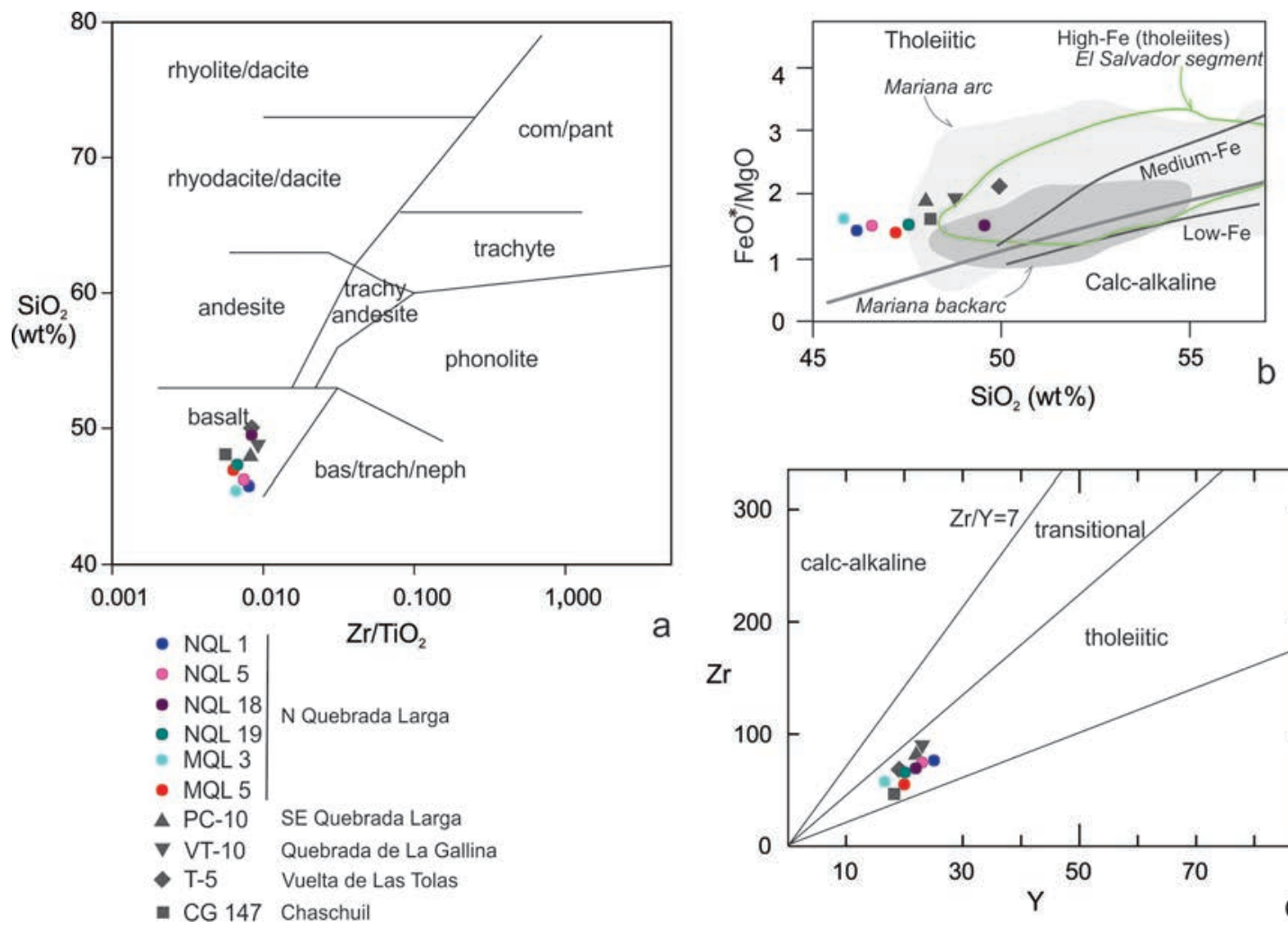

FIG. 11. Basalts and their related fragmented facies plotted in a. $\mathrm{Zr} / \mathrm{TiO}_{2}$ versus $\mathrm{SiO}_{2}$ diagram (after Winchester and Floyd, 1977; Pearce, 1996); b. $\mathrm{SiO}_{2}$ versus $\mathrm{FeO} * \mathrm{MgO}$ diagram (after Miyashiro, 1974). Mariana basin data from Ribeiro et al. (2013); El Salvador Segment (Central American Volcanic Arc) data from Patino et al. (2000); c. Y versus Zr diagram (after Barrett and McLean, 1999).

concentrations are also characteristics of the lowTi series (cf. Cummins et al., 1992; Peate et al., 1992), as observed in abundances of $\mathrm{Cr}=85-199$ ppm, $\mathrm{Ni}=18-63$ ppm, $\mathrm{Zr}=44-78 \mathrm{ppm}, \mathrm{Nb}<10 \mathrm{ppm}$, $\mathrm{Hf}=1.38-1.77 \mathrm{ppm}, \mathrm{Th}=1.75-2.07 \mathrm{ppm}, \mathrm{U}=0.46-0.50$ ppm, $\mathrm{Sr}=103-211$ ppm, $\mathrm{Ba}=51-488 \mathrm{ppm}, \mathrm{V}=203-274$ ppm and $\mathrm{Sc}=30-40$.

The chondrite-normalized REE patterns (after Boynton, 1984) of the analyzed rocks are shown in figure 12a. The ratio of $\mathrm{Sm}_{\mathrm{N}} / \mathrm{Yb}_{\mathrm{N}}=0.29-0.41$, also showing a slight enrichment of LREE relative to the HREE, with $\mathrm{La}_{\mathrm{N}} / \mathrm{Yb}_{\mathrm{N}}=0.80-1.27$. The moderate or absent $\mathrm{Eu}$ anomaly $\left(\mathrm{Eu} / \mathrm{Eu}^{*}=0.80-1.15\right)$ denotes a slight or no previous fractionation of plagioclase in the basalts.

In a spider diagram, trace elements normalized to N-MORB (after Sun and McDonough, 1989), the basalts (Fig. 12b) display features corresponding to volcanic arcs basalts, such as $\mathrm{Nb}$ depletion respect of $\mathrm{Ce}$ and enrichment in $\mathrm{Rb}$ and $\mathrm{Ba}$. The relatively high contents of $\mathrm{Pb}$ determined from some samples (Table 1) are typical of subduction environments. The tenors of $\mathrm{Ti}$ and $\mathrm{Y}$ are comparable to those of MORB, but also compatible with basalts from volcanic arcs (Pearce et al., 1984). Moreover the contents of rare earths have an almost flat design (Fig. 12b), with slight slope increases towards the LREE with enrichments of 1 to 1.5 times MORB values.

The tectonic environment for the emplacement of the analyzed basalts can also be studied in different discrimination diagrams. In the V-Ti/1000 diagram (Shervais, 1982) the studied basalts plot between the fields of the arc tholeiitic basalt and the MORB-BAB ones (Fig. 13a) and in the Ti-Zr diagram (after Pearce, 1982; Condie, 1989) they 

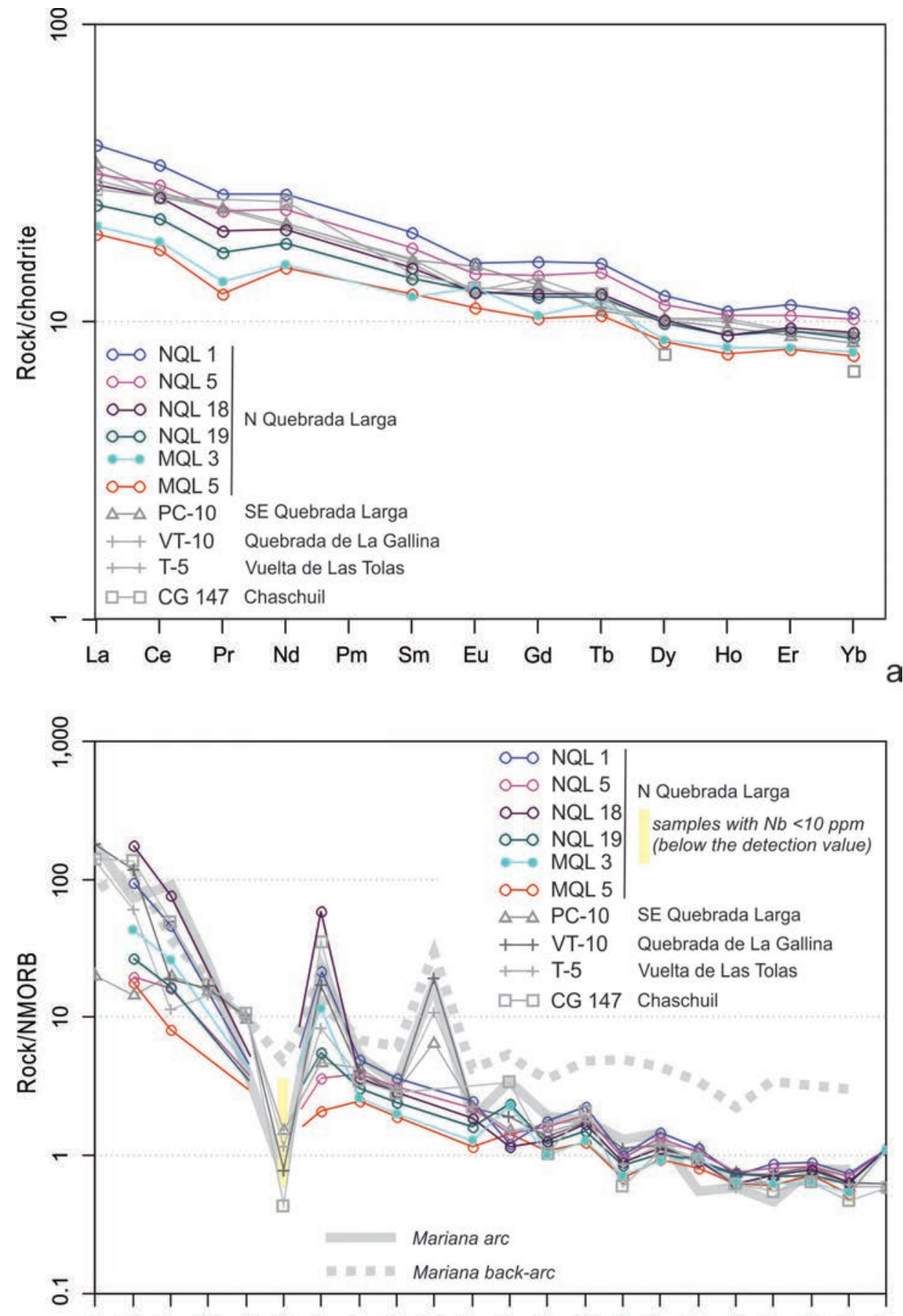

Cs $\mathrm{Rb} B a$ Th $\mathrm{U}$ Nb K La Ce Pb Pr Sr P Nd Zr Sm Eu Ti Dy Y Yb Lu

FIG. 12. Multi-element (spider) diagrams for the basalts and their related fragmented facies. a. Chondrite-normalized REE plots (after Boynton, 1984); b. N-MORB- normalized plots using normalizing factors of Sun and McDonough (1989). Mariana basin data from Ribeiro et al. (2013). 

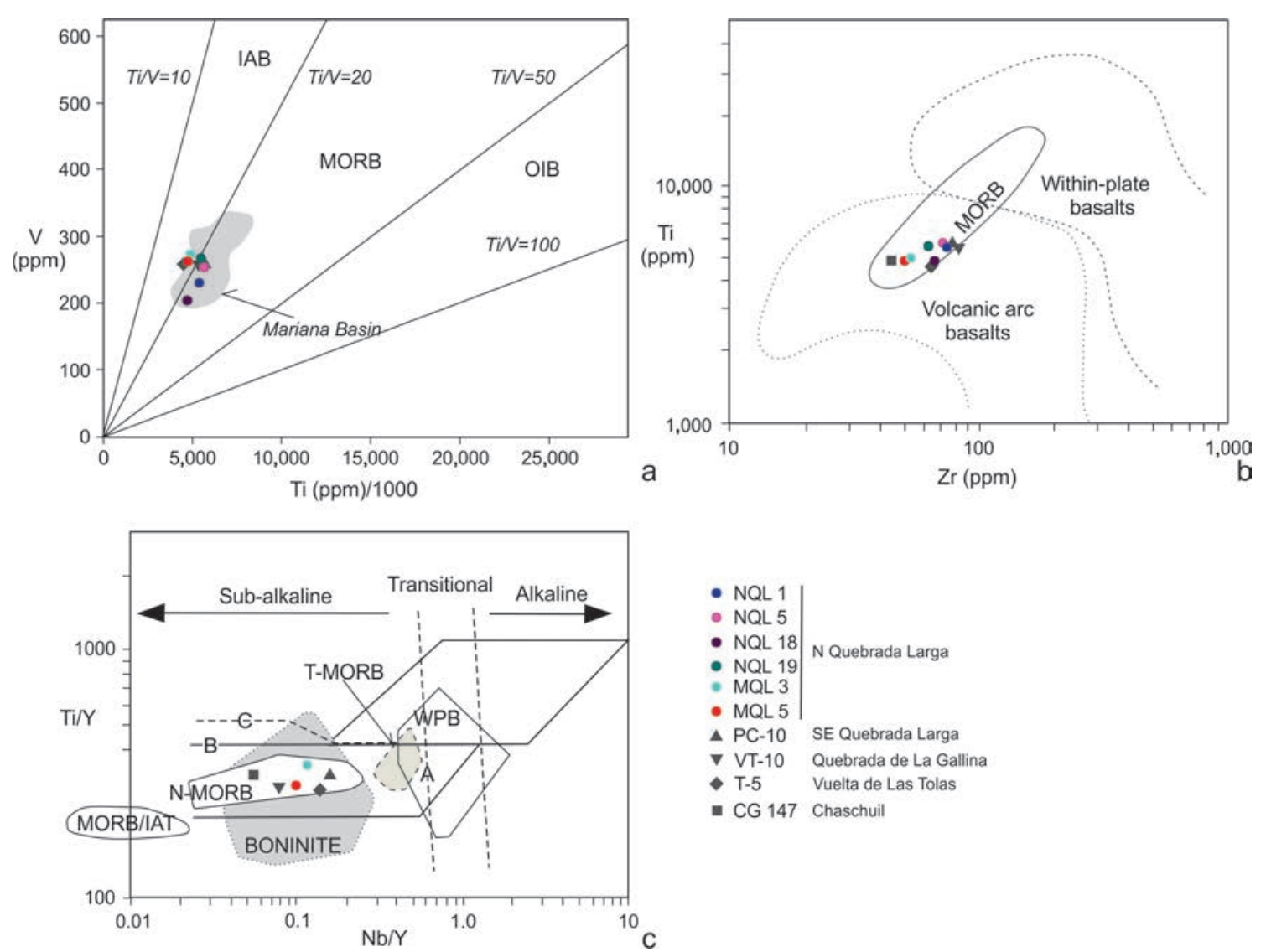

FIG. 13. a. Ti versus V diagram (Shervais, 1982). Mariana basin data from Ribeiro et al. (2013); b. Ti-Zr diagram (after Pearce, 1982; Condie, 1989) where the analyzed basalts plot along the MORB field; c. Ti/Y versus Nb/Y diagram (modified form Pearce, 1982) without samples with $\mathrm{Nb}<10$ (Table 1), to not produce erroneous interpretations. Fields: A: within plate; B: mid-ocean ridge; $\mathrm{C}$ : volcanic arc; MORB/IAT, mid-oceanic ridge basalt/island arc tholeiite; N-MORB, normal MORB; T-MORB, transitional MORB; WPB, within-plate basalts. Mariana basin data from Ribeiro et al. (2013).

fall in the MORB field within the volcanic arc basalts (Fig. 13b). In the Ti/Y-Nb/Y -diagram (Pearce, 1982) the samples plot along the N-MORB field (Fig. 13c).

\section{Discussion}

The basalts and the associated autoclastic to hyaloclastic facies studied in this paper integrate the lower portion of the Arenigian succession that crops out along the Las Planchadas range. They were studied together with other basaltic volcanic and volcaniclastic rock successions that crop out to the south (Fig. 2) and were compared with the Ordovician volcanic rocks located to the northwestern part of the Puna to define their evolving tectonic setting at that time.

\subsection{Emplacement environment}

All of these Arenigian deposits are composed by facies associations of a subaqueous depositional environment, as shown by the well-preserved structures (lava flows, autoclastic facies and the related basaltic hyaloclastites).

Magma-water interaction can produce a wide variety of volcanic textures and structures ranging from pillow lavas, autobrecciation of lava flows and hyaloclastites formed by non-explosive interaction and fine-grained widely dispersed pyroclasts formed 
by violent hydrovolcanic explosions (Carr and Jones, 2001). The structural and textural characteristics of the analyzed deposits can be generated by nonexplosive magma-water interaction processes. The autoclastic basaltic facies, closely related to the massive lavas bodies, testify for a non-explosive fragmentation. Basaltic flows may be cooler and more viscous and may be subject to locally higher strain rates than other emplacements of massive basalts. They respond to stress in a brittle mode and develop blocks of lava, located at the margins of the lava bodies or dislodged by continuous movement of the flow (cf. Mc Phie et al., 1993). In the study area, evidence for the cited process is the presence of autoclastic basaltic facies where the basaltic lavas are intensively fractured and show jigsaw-structures, with blocky clasts with curviplanar fracture surfaces and non-quenched margins.

The presence of Arenigian basaltic pillow breccias to the south of the study area (Quebrada Larga) also point to the non-explosive magma-water interaction.

To the south, along the Quebrada Larga area (Fig. 2), the same Arenigian succession is composed by basalts and their autoclastic facies, hyaloclastites and pillow breccias (Cisterna et al., 2010a) in close spatial relationship to marine fosiliferous sediments (Fig. 3). It is possible to compare these deposits, based on their close spatial and temporal relationships, with ancient volcanic successions where basaltic massive and fragmented lava flows are dominant in the proximal section and replaced in the most distal part by pillow lavas and/or pillow fragmented breccias (Quebrada Larga-de La Gallina area) (cf. Dimroth et al., 1978; Waters and Wallace, 1992).

\subsection{Nature of the monomictic basaltic breccias}

Hyaloclastites are composed by clastic aggregates formed by the non-explosive fracturing and disintegration of quenched lavas (cf. Rittmann, 1962). Autobrecciation and quench fragmentation probably operate together during the disintegration process of the subaqueous lava flow. Quenching produces fractures affecting the surface of the lavas. The clasts are formed in situ by the intersection of these fractures along the lava flow and by the spalling of quenched glass fragments (cf. McPhie et al., 1993). These clasts may range widely in size from less than one millimeter to tens of centimeters and may be entirely or partly glassy, vesicular or non-vesicular (cf. McPhie et al., 1993).

The exposed basaltic breccias in the study area are monomictic with clasts shapes that vary between slabby, flow-foliated with jagged ends, ragged or blocky clasts with curviplanar surfaces and display jigsaw structure. The clasts develop quenched margins and the fragment size may vary from less of one $\mathrm{mm}$ (millimeter) to $50 \mathrm{~cm}$ (centimeters). They show different textures, can be flow foliated, have a vitric groundmass or be highly vesicular. These rocks may be defined as in situ hyaloclastites because they display almost all the characteristics indicated for this type of deposits, as clasts with jigsaw texture, indicating that they remain in place while being fragmented (cf. McPhie et al., 1993).

The poorly sorted and quite chaotic nature of the breccia deposits suggests that they are proximal and formed next to its source. Furthermore, the occurrence of angular and fusiform blocks, with their glassy rinds frequently preserved, suggest that the breccia deposits were syn-eruptive, preferentially formed in the same space opened up in the lava flow, the site where temporary vents cause the hydro-magmatic activity (cf. Carr and Jones, 2001).

The mixture of fragments, either massive and angular or highly vesiculated and with glass rinds (Fig. 9), may be related to hydromagmatic episodes chiefly due to water-magma interaction, that relieved the pressure on the underlying melt, leading then to the sudden unmixing of the volatile component and to consequent magmatic fragmentation (cf. Dellino and La Volpe, 1995).

\subsection{Chemical features, magma source and tectonic setting}

The hyaloclastites show some chemical characteristics (e.g., low content $\mathrm{Fe}_{2} \mathrm{O}_{3}, \mathrm{MgO}$ and $\mathrm{Al}_{2} \mathrm{O}_{3}$ ) due to the partial mobilization of the ferromagnesian components by alteration processes. They also have higher amounts of $\mathrm{Zr}$ (average $123 \mathrm{ppm}$ and in basalts $64.5 \mathrm{ppm}$ ), that may be cause for a preferential enrichment in heavy accessory minerals (e.g., zircon) in the fine matrix. For this reason they are not included together with the basalts in the discrimination diagrams and not take into account in the tectonic interpretations.

Based on field relationships, petrography and chemical characteristics the studied basalts were 
correlated with the basalts and basaltic hyaloclastites exposed to the south of the Las Planchadas range (Quebrada Larga, Quebrada de La Gallina, Chaschuil and Vuelta de Las Tolas) with a similar geological context (Fig. 2). So their chemical data (unpublished) together with those obtained in the study area are considered to define the tectonic setting at the north portion of the Famatina System during Early Paleozoic.

Among the main geochemical characteristics of the studied basalts are $\mathrm{Zr}$, Ti and $\mathrm{Y}$ contents (e.g., Figs. 11 and 12) typical of depleted mantle sources (cf. Pearce et al., 1984) and enrichment in LILE components (e.g., average of Rb content $=148.5 \mathrm{ppm}$ and $\mathrm{Ba} / \mathrm{La}$ ratio of 20.42 ), reflecting a subduction related signature (cf. Pearce et al., 1984). Such features may be compared with basalts emplaced along arc-backarc basins systems, where the lava compositions are indicative of mid-ocean ridge basalt (MORB)-like sources with high water contents (cf. Taylor and Martínez, 2003). A depleted mantle source for the magma is also consistent with the observed $\mathrm{Nb} / \mathrm{Yb}$ ratio displayed for the studied basalts, 1.34 in average (cf. Elliott, 2003; Pearce et al., 2005).

The relatively low $\mathrm{Nb} / \mathrm{U}$ ratio (7.61-2.00) compared to the oceanic basalts (MORB and OIB)

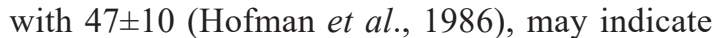
enrichment of $\mathrm{U}$ relative to $\mathrm{Nb}$ by flux of subduction related fluids and melts into the depleted mantle (c.f. Pearce, 2008). The same is pointing by the $\mathrm{Pb} / \mathrm{U}(4.33-11.94)$ and $\mathrm{Pb} / \mathrm{Ce}(0.09-0.27)$ ratios (c.f. Pearce, 2008).In subduction related systems high degrees of melting are associated with low ratios of more incompatible to less incompatible elements of relatively low fluid mobility (e.g., $\mathrm{La} / \mathrm{Yb}, \mathrm{Sm} / \mathrm{Lu}$, $\mathrm{Nb} / \mathrm{Y}$ and $\mathrm{Nb} / \mathrm{Zr}$ ) (c.f. Carr et al., 1990, 2003). For the studied basalts these ratios range between low to intermediate (average $\mathrm{La} / \mathrm{Yb}=4.88, \mathrm{Sm} / \mathrm{Lu}=6.38, \mathrm{Nb}$ / $\mathrm{Y}=0.11, \mathrm{Nb} / \mathrm{Zr}=0.03$ ) pointing to variable degrees of melting. Relatively low values for the $\mathrm{Sm} / \mathrm{Lu}$ ratio (3.62-11.67), U/Th (0.24-0.28) and $\mathrm{Sr} / \mathrm{Ce}$ (4.04-14.48) in the analyzed basalts reflect fluid fluxes into the mantle wedge possibly resulting in higher degrees of melting (e.g., Wehrmann et al., 2014).

The analyzed basalts show a positive correlation between $\mathrm{Th} / \mathrm{Yb}-\mathrm{Nb} / \mathrm{Yb}$ ratios (Fig. 14a) and fall on the volcanic arc domain with signature of a relatively depleted mantle source. On the $\mathrm{TiO}_{2} / \mathrm{Yb}$ versus $\mathrm{Nb} /$ $\mathrm{Yb}$ diagram (Fig. 14b), they fall along the MORB field denoting relatively shallow melting and normal MORB-like source components (cf. Pearce, 2008).
This ambivalence is characteristic for subduction related tholeiitic basalts. Similar characteristics have been observed, for example in volcanic rocks of the Central America Volcanic Arc (Figs. 14a, b), in particular in the El Salvador-Guatemala segments. There, a transition from volcanic arc to an extension related volcanism (back-arc) along an overriding plate progressively thicker has been mentioned (Morgan et al., 2008; Wehrmann et al., 2014). Similar variation has also been observed in volcanic rocks of the Marianas volcanic-arc (Morgan et al., 2008).

Marine sediments commonly have enrichment of elements that become fluid-mobile during subduction and their variations may be observed using ratios between highly fluid-mobile and less fluid-mobile incompatible trace elements. The relatively low values for the $\mathrm{Ba} / \mathrm{La}$ (7.7-54.2), $\mathrm{Ba} / \mathrm{Nb}(25.63-483.92)$ and U/Th (0.24-0.28) ratios of the basalts (Table 2) are comparable to the hemipelagic sediment from younger subduction systems such as the Central American Volcanic Arc (data from Heydolph et al., 2012; Wehrmann et al., 2014). The relatively high contents of Th (1.75-2.07 ppm), U (0.46-0.50 ppm) and $\mathrm{Nb}(1.00-3.05 \mathrm{ppm})$ in the basalts at the Las Planchadas range are supporting this idea.

All the previous geochemical considerations suggest for the studied basalts a depleted mid-ocean ridge basalt (MORB)-like source, modified by the contribution of subducted components derived from water rich marine sediments, features that are compatible with basalts emplacement along a back-arc basin.

As the back-arc-basin lavas (BAB) and midocean ridge basalts (MORB) are considered to be produces by adiabatic decompression of depleted mantle (cf. Ribeiro et al., 2013) and the arc and back-arc lavas formed by melting of a more hydrated and depleted mantle source (Reagan et al., 2010), the studied basalts could be explained by a magma generated by an adiabatic decompression melting of an hydrated and depleted mantle (cf. Ribeiro et al., 2013).

\subsection{The Famatina System in a regional geologic framework}

On the basis of the geochemical data here presented, together with the facies association observed in the Arenigian volcanic-volcaniclastic successions, it is possibly to consider the developing of a volcanic arc-back arc basin system during the Arenigian along 

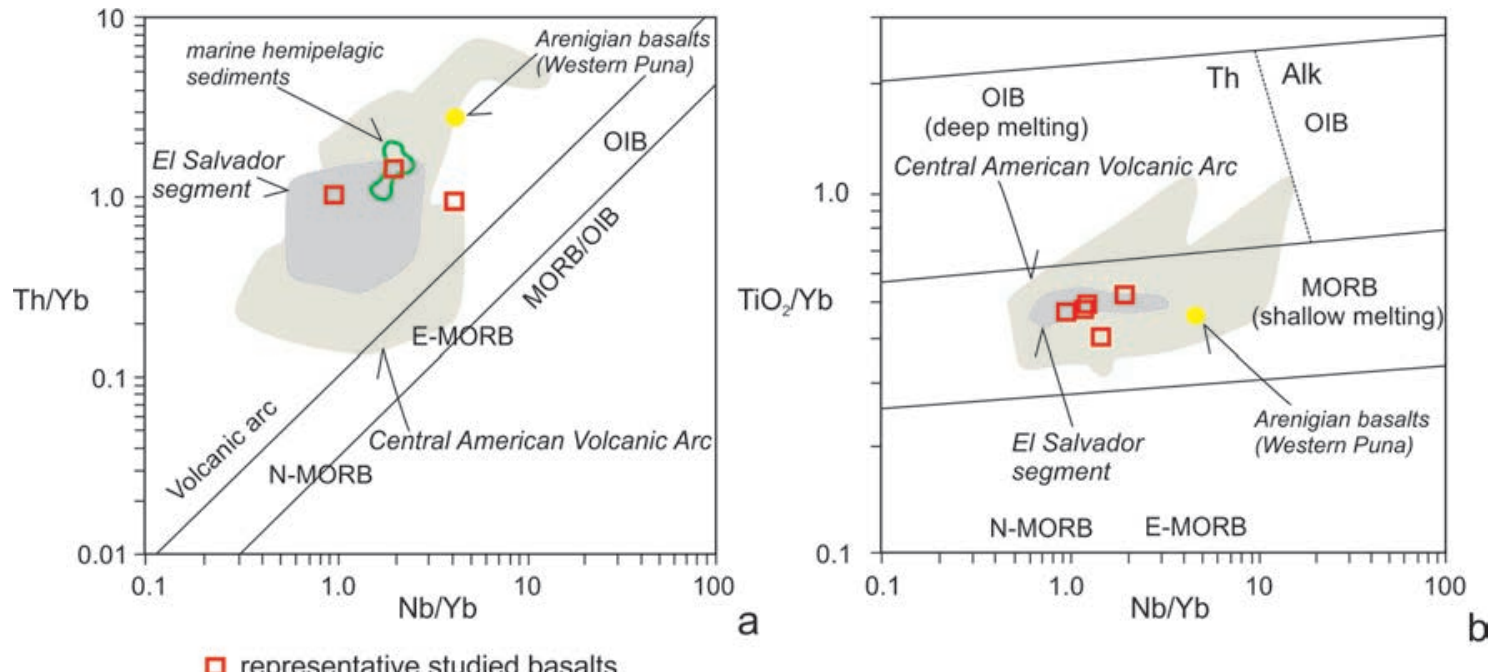

FIG. 14. a. $\mathrm{Th} / \mathrm{Yb}$ versus $\mathrm{Nb} / \mathrm{Yb}$ diagram (after Pearce, 2008). The compositions of input marine sediments are from Heydolph et al. (2012); b. $\mathrm{TiO}_{2} / \mathrm{Yb}$ versus $\mathrm{Nb} / \mathrm{Yb}$ diagram (after Pearce, 2008). Basalts from Western Puna data from Coira et al. (1999, 2009); El Salvador Segment and Central American Volcanic Arc data from Wehrmann et al. (2014).

TABLE 2. REE ELEMENTS RATIOS OF THE STUDIED BASALTS.

\begin{tabular}{|c|c|c|c|c|c|c|c|c|c|c|}
\hline \multirow{2}{*}{$\begin{array}{l}\text { Location } \\
\text { Sample } \\
\text { Rock type }\end{array}$} & \multirow[b]{2}{*}{$\begin{array}{l}\text { NQL1 } \\
\text { basalt }\end{array}$} & \multicolumn{5}{|c|}{ Northern Quebrada Larga } & $\begin{array}{l}\text { outheastern } \\
\text { Quebrada } \\
\text { Larga }\end{array}$ & $\begin{array}{l}\text { Quebrada de } \\
\text { La Gallina }\end{array}$ & $\begin{array}{l}\text { Vuelta de } \\
\text { Las Tolas }\end{array}$ & \multirow{2}{*}{$\begin{array}{c}\text { Chaschuil } \\
\text { CG-147* } \\
\text { basalt }\end{array}$} \\
\hline & & $\begin{array}{l}\text { NQL5 } \\
\text { basalt }\end{array}$ & $\begin{array}{c}\text { NQL18 } \\
\text { basalt }\end{array}$ & $\begin{array}{c}\text { NQL19 } \\
\text { basalt }\end{array}$ & $\begin{array}{c}\text { MQL3 } \\
\text { basalt }\end{array}$ & $\begin{array}{c}\text { MQL5 } \\
\text { basalt }\end{array}$ & $\begin{array}{l}\text { PC-10* } \\
\text { basalt }\end{array}$ & $\begin{array}{l}\text { VT-10* } \\
\text { basalt }\end{array}$ & $\begin{array}{c}\text { T-5* } \\
\text { basalt }\end{array}$ & \\
\hline $\mathrm{Ba} / \mathrm{La}$ & 24.5 & 10.2 & 54.2 & 13.6 & 25.7 & 8.5 & 11.9 & 11.9 & 7.7 & 36 \\
\hline $\mathrm{Ba} / \mathrm{Yb}$ & 127.80 & 48.57 & 256.84 & 55.26 & 98.23 & 31.87 & 70.00 & 61.98 & 38.30 & - \\
\hline $\mathrm{Ba} / \mathrm{Nb}$ & - & - & - & - & 483.92 & 25.63 & 36.00 & 65.38 & 27.07 & 313.00 \\
\hline $\mathrm{La} / \mathrm{Nb}$ & - & - & - & - & 0.31 & 0.33 & 0.33 & 0.18 & 0.29 & 0.11 \\
\hline $\mathrm{La} / \mathrm{Yb}$ & 5.22 & 4.76 & 4.74 & 4.05 & 3.82 & 3.81 & 5.89 & 5.21 & 4.95 & - \\
\hline $\mathrm{La} / \mathrm{Sm}$ & 3.08 & 2.86 & 3.00 & 2.85 & 2.71 & 2.54 & 3.36 & 3.24 & 2.92 & 9.05 \\
\hline $\mathrm{Nb} / \mathrm{Yb}$ & - & - & - & - & 1.17 & 1.24 & 1.94 & 0.95 & 1.41 & - \\
\hline $\mathrm{Nb} / \mathrm{Zr}$ & - & - & - & - & 0.04 & 0.04 & 0.04 & 0.02 & 0.04 & 0.02 \\
\hline $\mathrm{Nb} / \mathrm{U}$ & - & - & - & - & - & - & 7.61 & 3.79 & 5.32 & 2.00 \\
\hline $\mathrm{Pb} / \mathrm{Ce}$ & - & - & - & - & - & - & 0.09 & 0.27 & 0.15 & - \\
\hline $\mathrm{Pb} / \mathrm{U}$ & - & - & - & - & - & - & 4.33 & 11.94 & 6.44 & - \\
\hline $\mathrm{Sm} / \mathrm{Lu}$ & 7.80 & 7.00 & 6.00 & 5.40 & 4.80 & 4.80 & 11.67 & 11.03 & 1.69 & 3.62 \\
\hline $\mathrm{Sr} / \mathrm{Ce}$ & 4.04 & 5.65 & 4.90 & 11.72 & 13.93 & 9.21 & 6.20 & 8.02 & 6.17 & 14.48 \\
\hline $\mathrm{Sr} / \mathrm{Yb}$ & 47.39 & 61.90 & 54.21 & 111.05 & 122.94 & 80.62 & 76.11 & 88.54 & 71.28 & - \\
\hline $\mathrm{Th} / \mathrm{Nb}$ & - & - & - & - & - & - & 0.54 & 1.08 & 0.66 & 2.07 \\
\hline $\mathrm{Th} / \mathrm{Yb}$ & - & - & - & - & - & - & 1.04 & 1.03 & 0.93 & - \\
\hline $\mathrm{TiO}_{2} / \mathrm{Yb}$ & 0.40 & 0.46 & 0.41 & 0.49 & 0.48 & 0.49 & 0.53 & 0.47 & 0.40 & - \\
\hline $\mathrm{Yb} / \mathrm{La}$ & 0.19 & 0.21 & 0.21 & 0.25 & 0.26 & 0.26 & 0.17 & 0.19 & 0.20 & - \\
\hline
\end{tabular}

* Sample/or element analyzed in the Instituto de Geociências, Universidade de São Paulo.

- No data. 
the northern part of the Famatina System. Previously, during the Tremadocian, the volcanism in that region was related to the evolution of a marginal basin where depleted mantle derived melts (MORB) were produced and enriched through an extensional regime above the eastward dipping subducting slab (Cisterna et al., 2010b). Similar characteristics have been observed for the Tremadocian volcanism occurred along the western slope of the Puna (Coira et al., 2009).

During the Arenigian the magmatism at the western of the Puna was related to a volcanic arc-back-arc basin system, which evolved on attenuated continental crust (Coira et al., 2009), environmental conditions similar to those proposed for the studied basalts at Las Planchadas range. Taking into account the ages, petrographic and chemical similarities between the Ordovician volcanic successions cropping out along the northern part of the Famatina System and the western magmatic Puna Belt (Fig. 1c) it is possible to argue a common tectonic evolution and to support the interpretations that propose the development of an Ordovician Puna-Famatina subduction related magmatic arc-back arc system along the western margin of Gondwana.

\section{Conclusions}

The volcanic sequence analyzed at the middle portion Las Planchadas range, northern part of the Famatina System, consists of basaltic lava flows, autoclastic breccias and hyaloclastites facies denoting a subaqueous depositional environment, as shown by the well-preserved structures indicative of nonexplosive magma-water interaction. Sedimentary rocks, bearing Arenigian fossil fauna are intercalated in the upper part of the sequence.

The geochemical characteristics of the study basaltic rocks, such as LREE enriched REE patterns, enrichment in LILE, in particular $\mathrm{K}$ and $\mathrm{Pb}$, and $\mathrm{MgO}$, $\mathrm{Fe}_{2} \mathrm{O}_{3}, \mathrm{Ti}, \mathrm{Zr}, \mathrm{Y}, \mathrm{Nb}$ contents indicate a depleted midocean ridge basalt (MORB)-like source, modified by the contribution of subducted components derived from water rich marine sediments, features that are compatible with basalts emplacement along a back-arc basin.

Taking into account the ages, petrographic and chemical similarities between the Ordovician volcanic successions cropping out along the northern part of the Famatina System and the western magmatic Puna Belt it is possible to argue a common tectonic evolution and to support the interpretations suggesting the development of an Ordovician Puna-Famatina subduction related magmatic arc-back-arc system along the western margin of Gondwana.

\section{Acknowledgements}

This study was supported by the ANPCYT PICT 7- 8724, CONICET - PIP N ${ }^{\circ} 5115$ and CIUNT 26/G410, SECTER-UNJU 08/E015 Projects. H.H. Ulbrich thanks the São Paulo Science Foundation (Brazil) for financial support and C. Günter thanks the Institute of Earth and Environmental Science, Potsdam University (Germany); to A. Musiol and J. Artel (University of Potsdam) and A.M. Schleicher (GFZ Potsdam), for their assistance with the chemical analyses. The authors also thank the work of the reviewers.

\section{References}

Aceñolaza, F.G.; Toselli, A. 1984. Lower Ordovician volcanismin North West Argentina. In Aspects of the Ordovician System (Bruton, D.I.; editor). Palaeontological Contributions from the University of Oslo 295: 203-209. Oslo.

Aceñolaza, F.G.; Miller, H.; Toselli, A. 1996. Geología del Sistema del Famatina. Münchner Geologische Hefte A19: 1-411.

Albanessi, G.; Vaccari, N.E. 1994. Conodontos del Arenigiano en la Formación Suri. Sistema de Famatina, Argentina. Revista Española de Micropaleontología 26 (2): 125-146.

Astini, R.A. 1999. El Ordovícico del Sistema de Famatina. In Congreso Geológico Argentino, No. 14. Geología del Noroeste Argentino, No. 1, Relatorio: 152-158. Salta.

Astini, R.A.; Benedetto, J.I. 1996. Paleoenvironmental features and basin evolution of a complex volcanicarc region in the Pre-Andean western Gondwana: The Famatina Belt. In International Symposium on Andean Geodynamics, No. 3, Actas 1: 755-758. St. Malo.

Barrett, T.J.; MacLean, W.H. 1999. Volcanic sequences, lithogeochemistry and hydrothermal alteration in some bimodal volcanic-associated massive sulphides systems. Reviews in Economic Geology 8: 101-131.

Benedetto, J.L. 1994. Braquiópodos ordovícicos (Arenigiano) de la Formación Suri en la región del Río Chaschuil, Sistema del Famatina, Argentina. Ameghiniana 31: 221-238.

Benedetto, J.L. 1998. Early Paleozoic brachiopods and associated shelly faunas from western Gondwana: its bearing on the geodynamic history of the pre- 
Andean margin. In The proto-Andean margin of Gondwana (Pankhurst, R.; Rapela, C.W.; editors). Geological Society, Special Publications 142: 57-83. London.

Boynton, W.V. 1984. Geochemistry of the rare earth elements: meteorite studies. In Rare Earth Element Geochemistry (Henderson, P.; editor). Elsevier Publishing: 63-114. Amsterdam.

Brown, S.J.A.; Barley, M.E.; Krapez, B.; Cas, R.A.F. 2002. The Late Archaean Melita Complex, Eastern Goldfields, Western Australia: shallow submarine bimodal volcanism in a rifted arc environment. Journal of Volcanology and Geothermal Research 115: 303-327.

Busby, C.; Adams, B.F.; Mattinson, J.; Deoreo, S. 2006. View of an intact oceanic arc, from surficial to mesozonal levels: Cretaceous Alisitos arc, Baja California. Journal of Volcanology and Geothermal Research 149: 1-46.

Caroff, M.; Vidal, M.; Bénard, A.; Darboux, J. 2009. A late-Ordovician phreatomagmatic complex in marine soft-substrate environment: The Crozon volcanic system, Armorican Massif (France). Journal of Volcanology and Geothermal Research 184: 351-366.

Carr, M.J.; Feigenson, M.D.; Bennett, E.A. 1990. Incompatible element and isotopic evidence for tectonic control of source mixing and melt extraction along the Central American Volcanic Arc. Contributions to Mineralogy and Petrology 105: 369-380.

Carr, M.J.; Feigenson, M.D.; Patino, L.C.; Walker, J.A. 2003. Volcanism and geochemistry in Central America: progress and problems. In Inside the Subduction Factory. Geophysical Monograph (Eiler, J.; editor). The American Geophysical Union 138: 153-179.

Carr, P.F.; Jones, B.G. 2001. The influence of palaeoenvironment and lava flux on the emplacement of submarine, near-shore Late Permian basalt lavas, Sydney Basin (Australia). Journal of Volcanology and Geothermal Research 112: 247-266.

Cisterna, C.E. 1994. Contribución a la Petrología de los Granitoides del Extremo Norte de la Sierra de Narváez, Sistema de Famatina, Provincia de Catamarca. Thesis (Unpublished), Universidad Nacional de Salta: 219 p.

Cisterna, C.E.; Coira, B. 2014. Subaqueous eruption-fed mass-flow deposits: records of the Ordovician arc volcanism in the Northern Famatina Belt; Northwestern Argentina. Journal of South American Earth Sciences 49: 73-84.

Cisterna, C.E.; Coira, B.; Décima, F. 2010a. Efusiones subácueas del arco volcánico ordovícico en el norte del Sistema de Famatina. Revista de la Asociación Geológica Argentina 66: 223-235.

Cisterna, C.E.; Coira, B.; Koukharsky, M. 2010b. Sucesiones volcánicas-sedimentarias tremadocianas y arenigianas en la sierra de Las Planchadas-Narváez: registros evolutivos del arco magmático famatiniano. Revista de la Asociación Geológica Argentina 66: 178-191.

Clemens, K. 1993. Sedimentología, proveniencia y desarrollo geotectónico del Sistema de Famatina en el noroeste de Argentina durante el Paleozoico inferior. In Congreso Geológico Argentino, No. 2, Actas 1: 310-321. Mendoza.

Coira, B. 1975. Ciclo efusivo ordovícico registrado en la Formación Acoite, Abra Pampa, Provincia de Jujuy, Argentina. In Congreso Iberoamericano de Geología Económica, No. 2, Actas 1: 37-56. Buenos Aires.

Coira, B. 1979. Descripción Geológica de la Hoja 3C Abra Pampa, provincia de Jujuy. Servicio Geológico Nacional, Boletín 170: 1-90.

Coira, B. 2008. Volcanismo del Paleozoico inferior en la Puna Jujeña. In Geología y Recursos Naturales de la Provincia de Jujuy, Relatorio (Coira, B.; Zappettini, E.O.; editors). Asociación Geológica Argentina: 140154. Buenos Aires.

Coira, B.; Davidson, J.; Mpodozis, C.; Ramos, V. 1982. Tectonic and magmatic evolution of the Andes of northern Argentina and Chile. Earht Science Reviews 18: 303-332.

Coira, B.; Kay, S.M.; Pérez, B.; Woll, B.; Hanning, M.; Flores, P. 1999. Magmatic sources and tectonic setting of Gondwana margin Ordovician magmas, northern Puna of Argentina and Chile. In Laurentia-Gondwana connections before Pangea (Ramos, V.A.; Keppie, D.; editors). Geological Society of America Special Paper 336: 145-170. London.

Coira, B.; Koukharsky, M.; Ribeiro Guevara, S. 2002. Magmatismo básico del Paleozoico inferior en la Sierra de la Quebrada Honda, Puna Catamarqueña. Argentina. In Congreso Geológico Argentino, No. 2, Actas 1: 122-127. Calafate.

Coira, B.; Koukharsky, M.; Ribeiro Guevara, S.; Cisterna, C.E. 2009. Puna (Argentina) and Northern Chile Ordovician basic magmatism: A contribution to the tectonic setting. Journal of South American Earth Sciences 27: 24-35.

Condie, K.C. 1989. Geochemical changes in basalts and andesites across the Archean-Proterozoic boundary: identification and significance. Lithos 23: 1-18.

Conti, C.M.; Rapalini, A.E.; Coira, B.; Koukharsky, M. 1996. Paleomagnetic evidence of an early Paleozoic 
rotated terrane in nothwestArgentina: A clue from Gondwana-Laurentia interactions? Geology 24: 953-956.

Cuerda, A.J. 1965. Estratigrafía de los depósitos neopaleozoicos de la sierra de Maz (provincia de La Rioja). In Jornadas Geológicas Argentinas, No. 2, Actas 3: 79-94. Salta.

Cummins, L.E.; Arthur, J.D.; Ragland, P.C. 1992. Classification and tectonic implications for early Mesozoic magma types of the circum-Atlantic. In Eastern North American Mesozoic Magmatism (Puffer, J.H.; Ragland, P.C.; editors). Geological Society of America, Special Paper 268: 119-135. London.

Dellino, P.; La Volpe, I. 1995. Fragmentation versus transportation mechanisms in the pyroclastic sequence of Monte Pilato-Rocche Rosse (Lipari, Italy). Journal of Volcanology and Geothermal Research 64: 211-231.

Dimroth, E.; Cousineau, P.; Leduc, M.; Sanschagrin, Y. 1978. Structure and organization of Archean basalt flows, Rouyn-Noranda area, Quebec, Canada. Canadian Journal of Earth Science 15: 902-918.

Elliott, T.R. 2003. Tracers of the slab, in Inside the Subduction Factory. In Geophysical Monograph (Eiler, J.; editor). American Geophysical Union 23-45. Washington.

Harrington, H.J.; Leanza, A.F. 1957. Ordovician trilobites of Argentina. University of Kansas, Department of Geology, Special Publication 1: 1-276.

Heydolph, K.; Hoernle, K.; Hauff, F.; van den Bogaard, P.; Portnyagin, M.; Bindeman, I.; Garbe-Schönberg, D. 2012. Along and across arc geochemical variations in NW Central America: evidence for involvement of lithospheric pyroxenite. Geochimica et Cosmochimica Acta 84: 459-491.

Hofman, A.V.; Jochum, K.P.; Seufert, M.; White, W.M. 1986. $\mathrm{Nb}$ and $\mathrm{Pb}$ in oceanic basalts: new constraints on mantle evolution. Earth and Planetary Science Letters 79: 33-45.

Koukharsky, M.; Torres Claro, R.; Etcheverría, M.; Vaccari, N.E.; Waisfeld, B.D. 1996. Episodios volcánicos del Tremadociano y del Arenigiano en Vega Pinato, Puna salteña, Argentina. In Congreso Geológico Argentino, No. 13, Actas 5: 535-542. Buenos Aires.

Kretz, R. 1983. Symbols for rock-forming minerals. American Mineralogist 68: 277-279.

Mannheim, R. 1993. Génesis de las volcanitas eopaleozoicas del Sistema del Famatina, Noroeste de Argentina. In Congreso Geológico Argentino, No. 12, Actas 4: 147-155. Mendoza.
Mángano, M.G.; Buatois, L.A. 1996. Shallow marine event sedimentation in a volcanic arc-related setting: the Ordovician Suri Formation, Famatina Range, northwest Argentina. Sedimentary Geology 105: 63-90.

Mángano, M.G.; Buatois, L.A. 1997. Slope-apron deposition in an Ordovician arc-related setting: The Vuelta de Las Tolas member (Suri Formation), Famatina Basin, northwestern Argentina. Sedimentary Geology 109: 155-180.

Mángano, M.G.; Astini, R.A.; Buatois, L.A.; Dávila, F. M. 2003. The Ordovician System in the Famatina Belt: depositional and tectonic evolution. In Aspects of the Ordovician System in Argentina (Aceñolaza, F.C.; editor). Serie Correlación Geológica 16: 295 312. Tucumán.

McPhie, J.; Doyle, M.; Allen, R. 1993. Volcanic Textures: a guide to the interpretation of textures in volcanic rocks. CODES Key Centre, University of Tasmania, Hobart: 198 p. Tasmania.

Miyashiro, A. 1974. Volcanic rock series in island arcs and active continental margins. American Journal of Science 274: 321-355.

Morgan, J.P.; Ranero, C.R.; Vannucchi, P. 2008. Intra-arc extension in Central America: Links between plate motions, tectonics, volcanism, and geochemistry. Earth and Planetary Science Letters 272: 365-371.

Pankhurst, R.; Rapela, C.; Fanning, H. 2000. Age and origin of coeval TTG, I-and S-Type granites in the Famatinian belt of NW Argentina. Transactions of Royal Society of Edinburgh Earth Science 91: 151-168.

Patino, L.C.; Carr, M.J.; Feigenson, M.D. 2000. Local and regional variations in Central American arc lavas controlled by variations in subducted sediment input. Contributions to Mineralogy and Petrology 138: 265-283.

Pearce, J.A. 1982. Trace element characteristics of lavas from destructive plate boundaries. In Andesites (Thorpe, R.S.; editor). John Wiley and Sons: 528548. London.

Pearce, J.A. 1996. A User's Guide to Basalt Discriminations Diagrams. In Trace Element Geochemistry of Volcanic Rocks: Applications for Massive Sulphide Exploration (Wyman, D.A.; editor). Geological Association of Canada, Short Courses Notes 12: 79-113. London.

Pearce, J.A. 2008. Geochemical fingerprintring of oceanic basalts with applications to ophiolite classification and the search for Archean oceanic crust. Lithos 100: 14-48.

Pearce, J.A.; Lippard, S.J.; Roberts, S. 1984. Characteristics and tectonic significance of supra-subduction zone 
ophiolites. In Marginal Basin Geology (Kokelaar, B.P.; Howells, M.F.; editors). Geological Society, Blackwell Scientific Publications: 77-93. London.

Pearce, J.A.; Stern, R.J.; Bloomer, S.H.; Fryer, P. 2005. Geochemical mapping of the Mariana arc-basin system: Implications for the nature and distribution of subduction components. Geochemical and Geophysical Geosystems 6: Q07006. doi: 07010.01029/ 02004 GC000895.

Peate, D.W.; Hawkesworth, C.J.; Mantovani, M.S.M. 1992. Chemical stratigraphy of magma types and their spatial distribution. Bulletin of Volcanology 55: 119-139.

Petersen, C.S.; Leanza, A.F. 1953. Elementos de Geología Aplicada. Nigar: 475 p. Buenos Aires.

Ramos, V.A. 1988. Late Proterozoic-Early Paleozoic of South America: a collisional history. Episodes 11: 168-175.

Rapalini, A.E.; Astini, R.A.; Conti, C.M. 1999. Paleomagnetic constrains on the evolution of Paleozoic suspect terranes from South America. In Laurentia Gondwana connections before Pangea (Ramos, V.A.; Keppie, J.D.; editors). Geological Society of America, Special Paper 336: 171-182. London.

Reagan, M.K.; Ishizuka, O.; Stern, R. 2010. Fore-arc basalts and subduction initiation in the Izu-Bonin-Mariana system. Geochemical and Geophysical Geosystems 11: Q03X12. doi: 10.1029/2009GC002871.

Ribeiro, J.M.; Stern, R.J.; Kelley, K.; Martínez, F.; Ishizuka, O.; Manton, S.W.; Ohara, Y. 2013. Nature and distribution of slab-derived fluids and mantle sources beneath the Southeast Mariana forearc rift. Geochemical and Geophysical Geosystems 14 (10): 4585-4607. doi: 10.1002/ggge.20244.

Rittmann, A. 1962. Volcanoes and their activity. John Wiley and Sons: 305 p. New York.

Rubiolo, D.; Cisterna, C.E.; Villeneuve, M. 2002. Edad $\mathrm{U} / \mathrm{Pb}$ del granito de Las Angosturas en la sierra de Narváez (Sistema de Famatina, provincia de Catamarca). In Congreso Geológico Argentino, No. 15, Actas 1: 359-362. Calafate.

Saavedra, J.; Toselli, A.J.; Rossi, J.N.; Pellitero, E.; Durand, F.R. 1998. The Early Paleozoic magmatic record of the Famatina System: a review. In The Proto-Andean margin of Gondwana: (Pankhurst, R.J.; Rapela, C.W.; editors). Geological Society of London, Special Publication 142: 283-295. London.

Shervais, J.W. 1982. Ti-V plots and the petrogenesis of modern and ophiolitic lavas. Earth and Planetary Science Letters 59: 101-118.
Slavutsky, E.J. 2009. Secuencia volcánica- sedimentaria ordovícica en el norte del Sistema de Famatina: caracterización de litotipos en la zona de la quebrada de la Punta Colorada, sierra de las Planchadas, Suroeste de Catamarca. Tesis de Grado (Inédita) Universidad Nacional de Tucumán, Facultad de Ciencias Naturales: 71 p.

Sun, S.S.; McDonough, W.F. 1989. Chemical and isotopic systematics of oceanic basalts; implications for mantle composition and processes. In Magmatism in the ocean basins (Saunders, A.D.; Norry, M.J.; editors). Geological Society of London 42: 313-345. London.

Taylor, B.; Martínez, F. 2003. Back-arc basin basalt systematics. Earth and Planetary Science Letters 210: 481-497.

Templeton, J.H.; Hanson, R.E. 2003. Jurassic submarine arc-apron deposits and associated magma/wet-sediment interaction, northern Sierra Nevada, California. Journal of Volcanology and Geothermal Research 128: 299-326.

Toselli, A.J.; Durand, F.R.; Rossi de Toselli, J.N.; Saavedra, J. 1996. Esquema de evolución geotectónica y magmática eopaleozoica del Sistema de Famatina y sectores de Sierras Pampeanas. In Congreso Geológico Argentino, No. 13, Actas 5: 443-462. Buenos Aires.

Turner, J.M. 1958. Estratigrafía de la Sierra de Narváez, Catamarca. Revista de la Asociación Geológica Argentina 12: 18- 60.

Turner, J.M. 1960. Estratigrafía del tramo medio de la Sierra de Famatina y adyacencias (La Rioja). Academia Nacional de Ciencias 42: 77-126. Córdoba.

Turner, J.M. 1967. Descripción Geológica de la Hoja Geológica 13b, Chaschuil (Provincias de Catamarca y la Rioja). Instituto Nacional de Geología y Minería, Boletín 106: 1-123. Buenos Aires.

Vaccari, N.E.; Wasisfeld, B.G. 1994. Nuevos trilobites de la Formación Suri (Ordovícico Temprano) en la región de Chaschuil, provincia de Catamarca. Implicancias bioestratigráficas. Ameghiniana 31: 73-86.

Viramonte, J.M.; Becchio, R.A.; Viramonte, J.G.; Pimentel, M.M.; Martino, R.D. 2005. New U/Pb and Sm-Nd data for the Ordovician magmatism on the eastern border of the southern Puna. In Congreso Geológico Argentino, No. 14, Actas 1: 191-198. Salta.

Waters, J.C.; Wallace, D.B. 1992. Volcanology and sedimentology of the host succession to the Hellyer and Que River volcanic-hosted massive sulfide deposits, northwestern Tasmania. Economic Geology 87: 650-666. 
Wehrmann, H.; Hoernle, K.; Garbe-Schönberg, D.; Jacques, G.; Mahlke, J.; Schumann, K. 2014. Insights from trace element geochemistry as to the roles of subduction zone geometry and subduction input on the chemistry of arc magmas. International Journal of Earth Sciences 103: 1929-1944.

White, J.D.L. 2000. Subaqueous eruption-fed density currents and their deposits. Precambrian Research 101: 87-109.
White, J.D.L.; Busby-Spera, C.J. 1987. Deep marine arc apron deposits and syndepositional magmatism in the Alisitos Group at Punta Cono, Baja California, México. Sedimentology 34: 911-927.

Winchester, J.A.; Floyd, P.A. 1977. Geochemical discrimination of different magma series and their differentiation products using immobile elements. Chemical Geology 20: 325-343.

Manuscript received: August 13, 2016; revised/accepted: March 1, 2017; available online: March 1, 2017. 